\title{
Geophysical Footprints of Cotopaxi's Unrest and Minor Eruptions in 2015: An Opportunity to Test Scientific and Community Preparedness
}

\author{
Patricia A. Mothes, Mario C. Ruiz, Edwin G. Viracucha, \\ Patricio A. Ramón, Stephen Hernández, Silvana Hidalgo, \\ Benjamin Bernard, Elizabeth H. Gaunt, Paul Jarrín, \\ Marco A. Yépez and Pedro A. Espín
}

\begin{abstract}
Cotopaxi volcano, Ecuador, experienced notable restlessness in 2015 that was a major deviation from its normal background activity. Starting in April and continuing through November 2015 strong seismic activity, infrasound registry, hikes in $\mathrm{SO}_{2}$ degassing and flank deformation with small displacements were some of the geophysical anomalies that were registered. Obvious superficial changes, such as small hydromagmatic eruptions, emission of vapor and ash columns, thermal hotspots around the crater and in nearby orifices and exacerbated glacier melting were also observed. Our contribution provides an overview of the 2015 Cotopaxi unrest by presenting the patterns of geophysical data and the sequence of events produced by the volcano. Cotopaxi's last important VEI 4 eruption was in 1877. Then it had devastating effects because of the transit of huge lahars down 3 major drainages. Comparatively, the 2015 activity never surpassed a magnitude VEI 2 and principally produced limited hydromagmatic explosions and semi-continuous low energy emissions and light ashfalls. Given the potential of major destruction from a large Cotopaxi eruption it is important to understand the geophysical fingerprints that characterized the 2015 episode with an eye to identifying onset of future restless periods. Overall, the monitoring activities, the data interpretation, formulation of reasonable eruptive scenarios, and finally, the preparation of a stream of constant information being relayed to concerned authorities and the public, was a real test of the IGEPN's capacity to deal with a complicated eruption situation whose outcome was not apparent at the beginning, but which concluded in a very small eruptive episode.
\end{abstract}

P.A. Mothes $(\varangle) \cdot$ M.C. Ruiz · E.G. Viracucha •

P.A. Ramón · S. Hernández $\cdot$ S. Hidalgo $\cdot$ B. Bernard ·

E.H. Gaunt · P. Jarrín · M.A. Yépez · P.A. Espín

Instituto Geofísico, Escuela Politécnica Nacional,

Quito, Ecuador

e-mail: pmothes@igepn.edu.ec

Advs in Volcanology (2019) 241-270

DOI 10.1007/11157_2017_10

(C) The Author(s) 2017

Published Online: 19 July 2017 


\section{Resumen}

En 2015 el volcán Cotopaxi, Ecuador experimento un notable cambio, que fue una desviación importante de su actividad normal de base. A partir de abril y hasta noviembre de 2015 fuerte actividad sísmica, registros de infrasonido, incremento en la desgasificación de $\mathrm{SO}_{2}$ y pequeños cambios en la deformación de los flancos fueron algunas de las anomalías geofísicas registradas. Evidentes cambios superficiales también fueron observados como pequeñas erupciones hidromagmaticas, emisión de vapor, columnas de cenizas, puntos calientes alrededor del cráter y el deshielo de los glaciares. Nuestra contribución proporciona una visión general de las anomalías del Cotopaxi en el 2015, mediante la presentación de patrones de los datos geofísicos y la secuencia de eventos producidos por el volcán. La última erupción importante del Cotopaxi fue un VEI 4 en 1877. Esta tuvo efectos devastadores debido al descenso de enormes lahares por sus tres drenajes mayores. Comparativamente, la actividad del año 2015 nunca superó una magnitud VEI 2, principalmente produciendo explosiones hidromagmaticas, escasas emisiones y leves caídas de ceniza. Debido a la potencial destrucción por una eventual erupción grande del Cotopaxi es importante entender los registros geofísicos que caracterizó el episodio de 2015 para poder identificar el inicio de futuros períodos eruptivos. En general, las actividades de vigilancia, la interpretación de datos, formulación de escenarios eruptivos razonables y por último, la preparación de un flujo de información constante que llegue a las autoridades interesadas y el público, fue una verdadera prueba de la capacidad del IGEPN para hacer frente a una situación de erupción cuyo resultado no era evidente al principio, pero que finalizó como una erupción pequeña.

\section{Keywords}

Volcanic unrest - Precursory geophysical patterns - Precursory LPs and VLPs • Volcano monitoring - Cotopaxi volcano-Ecuador - State of preparedness

\section{Introduction}

Long dormant volcanoes that begin to awaken may have start and stop activity that has to be evaluated with respect to the volcano's known past. A volcano's past activity is known by study of its stratigraphy, other physical evidence and possibly historical chronicles (Tilling 1989). Many uncertainties preclude knowing the final outcome of a restless volcano (Newhall 2000; Sparks and Aspinall 2004), since a volcano may awaken for short term low-level activity, then resume repose until additional magma inputs herald an episode of further unrest (Phillipson et al. 2013). Eruptions that barely bring magma to the surface may be classified as "failed", since so little juvenile magma erupts (Moran et al. 2011).

At Cotopaxi ample geological and historical information exists with regard to its past activity (Hall and Mothes 2008; Garrison et al. 2011; Pistolesi et al. 2012). Formulation of eruptive 
scenarios with respect to the 2015 unrest period were based on our collective knowledge of the volcano's geology and eruptive history and published information as well as interpretation of the abundant geophysical data streams available through instrumental and observational networks operated by the Instituto Geofísico of the Escuela Politécnica Nacional (IGEPN)-Quito, Ecuador, the entity in charge of volcano and tectonic monitoring in Ecuador. The combination of these inputs allowed scientists at the IGEPN to transmit a coherent image of the evolving unrest presented during 2015 and to indicate the most likely eruption/activity scenarios. Two earlier unrest periods are known: 1975-1976, when the IGEPN had limited seismic equipment operating on the volcano and then in 2001-2002. Both periods were comprised of increased fumarolic activity both inside and outside of the crater and a hike in seismicity for the 2001 period (Molina et al. 2008). The 2015 unrest displayed important changes in seismic and deformation patterns, gas output and superficial activity, compared to background, whose level was established since around 1990. In sum, Cotopaxi's 2015 unrest displayed a progressive crescendo of geophysical signals, then minor hydromagmatic explosions, followed by overall seismic energy decrease at the end of 2015, which was accompanied by fewer superficial manifestations. Like many other volcanoes that have displayed unrest, this recent episode did not culminate in a full-fledged eruption with large volumes of juvenile pyroclastics (Phillipson et al. 2013). Moran et al. (2011) maintain that an eruption is "failed" when magma reaches but does not pass the "shallow intrusion" stage, i.e., the magma gets close to, but does not reach the surface. In the actual case, the amount of erupted material was minor, and had a dense rock equivalent volume of $\sim 0.5 \mathrm{Mm}^{3}$ (Bernard et al. 2016).

\section{Cotopaxi Volcano}

Cotopaxi volcano, located in central Ecuador atop the Eastern Cordillera, is a large, symmetrical stratocone with a basal diameter of $18 \mathrm{~km}$ and an altitude of $5897 \mathrm{~m}$ (Hall and Mothes 2008). Its actual glacier cap of $10.49 \mathrm{~km}^{2}$ is rapidly diminishing due to climatic change Cáceres et al. (2016) (Fig. 1). The volcano's last important VEI $=4$ eruption was on 26 June 1877. Then it generated highly erosive pyroclastic flows that melted glaciers and triggered voluminous lahars $\left(\sim 100 \mathrm{Mm}^{3}\right.$ per drainage). Each lahar traveled hundreds of kilometers down several drainages enroute to the Amazon basin, Pacific Ocean and to the Atlantic, respectively (Mothes et al. 2004; Mothes and Vallance 2015). These past lahar routes now host sprawling suburbia, important economic activities and vital infrastructure. Ecuador's second most visited national park (Parque Nacional Cotopaxi-PNC) is centered on the volcano and draws some 200,000 tourists a year.

The volcano's five most important eruptive episodes during the historical period (since 1532) have been of andesitic composition and ranged between VEI $=3$ and 4 (Pistolesi et al. 2012). Nonetheless, the volcano is bi-modal and produces VEI $=5$ rhyolitic eruptions about every 2000 years (Hall and Mothes 2008). The last important rhyolitic eruption, the Peñas Blancas event, occurred about 2800 years BP (Mothes et al. 2015a). The youngest andesitic eruptive products contain intergrowths of plagioclase and pyroxene and four different populations of plagioclase crystals which indicate pervasive magma mixing (Garrison et al. 2011).

Given the high probability for the generation of long-distance lahars, wide dispersal of pyroclastic fall, and the consequential negative impact on many economic activities and the compromise of critical infrastructure should an eruptive period last for months to years, Cotopaxi is considered a "National" volcano, located in the center of Ecuador, near to Quito, the capital and other populated areas. Even a short-lived VEI 4 eruption (VEI = Volcano Explosivity Index) (Newhall and Self 1982) has the potential to gravely affect Ecuador's overall productivity and major transport lines. Lastly, the volcano is considered one of the most dangerous in Ecuador, given the possible exposure of $>300,000$ residents to primary lahars and ashfalls during 


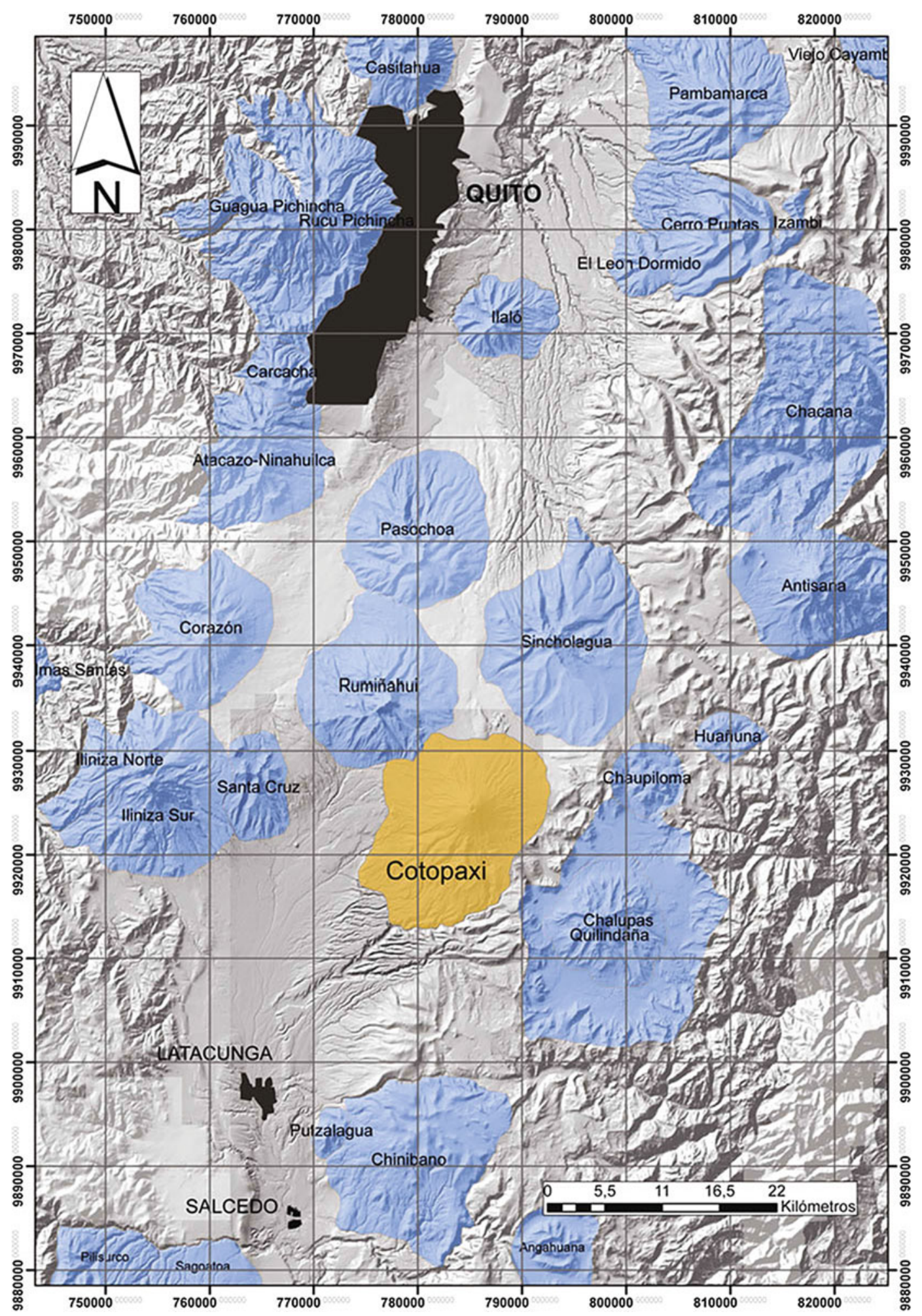

Fig. 1 Location of Cotopaxi volcano in Ecuador's Inter-Andean Valley and major cities 
future VEI $=3$ or greater magnitude eruptions (Mothes et al. 2016a).

\section{Monitoring Cotopaxi}

Cotopaxi has long been a producer of swarms of LP's, and Ruiz et al. (1998) hypothesized that they were related to the interaction of the hydrothermal system with heat ascending from depth. During unrest in 2001-2002 thousands of long period, volcano-tectonic and distal volcano-tectonic seismic events were registered and magma was hypothesized to have ascended to shallow levels in the center of the edifice (Molina et al. 2008). Its flanks also experienced deformation from magma input estimated at $\sim 20 \mathrm{Mm}^{3}$ from modeling of EDM data (Hickey et al. 2015). But, observable superficial manifestations were meager, no magma erupted and the volcano returned to a relatively quiet state with only short-lived LP swarms (Lyons et al. 2012) and sporadic VLP events being registered until April, 2015 (Márquez 2012; Arias et al. 2015).

The IGEPN has monitored Cotopaxi volcano since 1986. Subsequently, over the years the monitoring coverage has become denser and more robust (Fig. 2) (Kumagai et al. 2007, 2009, 2010). Presently there are approximately 60 telemetered geophysical sensors operating on its flanks. Cotopaxi hazard maps have been published in several versions since 1976, with the newest version published in late 2016 (Mothes et al. 2016a). The IGEPN has carried out a long-term program of community education for areas that are at highest risk, although as noted by Christie et al. (2015), the attention over such a vast area $\left(\approx 2000 \mathrm{~km}^{2}\right)$, was uneven.

Cotopaxi was a VUELCO target volcano from 2013 to 2015. As part of the VUELCO project, in November 2014 a simulation exercise was carried out with the purpose of presenting a timeline of potential unrest and expected events and to test the communication between scientists, decision-makers and the public (www.vuelco.net ). This present contribution is written in the spirit of holistically documenting this recent and most serious unrest of Cotopaxi to date-since 1942, when slight ash emissions and mild explosive activity were then reported (Siebert et al. 2010). Here we present the macro patterns of seismic, gas, deformation and visual observation monitoring data associated with the awakening volcano. The data are provided by the monitoring networks operated by the IGEPN. We avoid dwelling on details, as forthcoming contributions dedicated to exploiting specific datasets are in preparation. We also provide comment on selected actions in which IGEPN scientists participated to make the overall societal outcome more favorable in case Cotopaxi produced a major eruption. We impart with the philosophy, stated in Marzocchi et al. (2012) that "sound scientific management of volcanic crises is the primary tool to reduce significantly volcanic risk in the short-term". We also maintain that a constant and rapid analysis of the monitoring data is key to giving forecasts that include reasonable scenarios. Some of the IGEPN actions were guided by experiences gained in the VUELCO project, since one of the scenarios in the simulated eruptions was that the volcano would wake up, be active then return to repose.

The 14th of August, 2015 explosions and subsequent emissions pushed the first evidence of new magma to the surface, although in a limited way (Gaunt et al. 2016). Documentation of the geophysical signals and observations that we registered through late 2015 leads to the depiction of what transpired-mainly of an intrusion, which stayed deep, although the signs of intrusions that stall at depth may be very similar to those produced by intrusions that finally do erupt (e.g. Moran et al. 2011).

\section{Synthesis of the Geophysical Fingerprints of the Unrest}

Having passed 13 years with low levels of activity since cessation in 2002 of its last reactivation, in mid-April 2015 Cotopaxi began departing from background levels: higher seismic energy release, gas outputs and superficial manifestations transpired. The height of activity was 


\section{COTOPAXI VOLCANO MONITORING NETWORK INSTITUTO GEOFISICO-EPN}

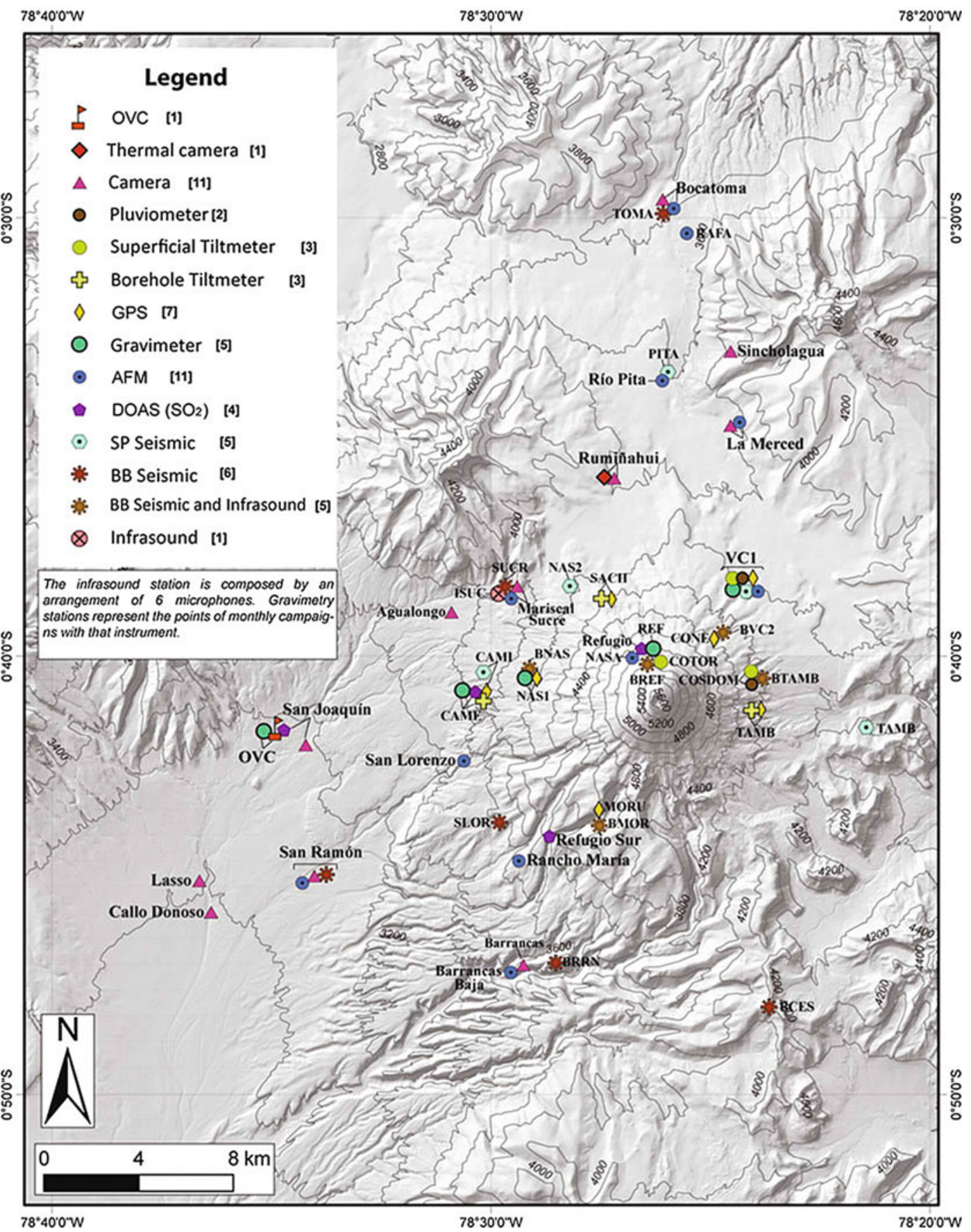

Fig. 2 Map of the instrumental monitoring network around Cotopaxi volcano, April 2016 


\section{Daily RMS values of BREF seismic station-vertical component}

(a) 01 January, 2015 -01 April, 2016

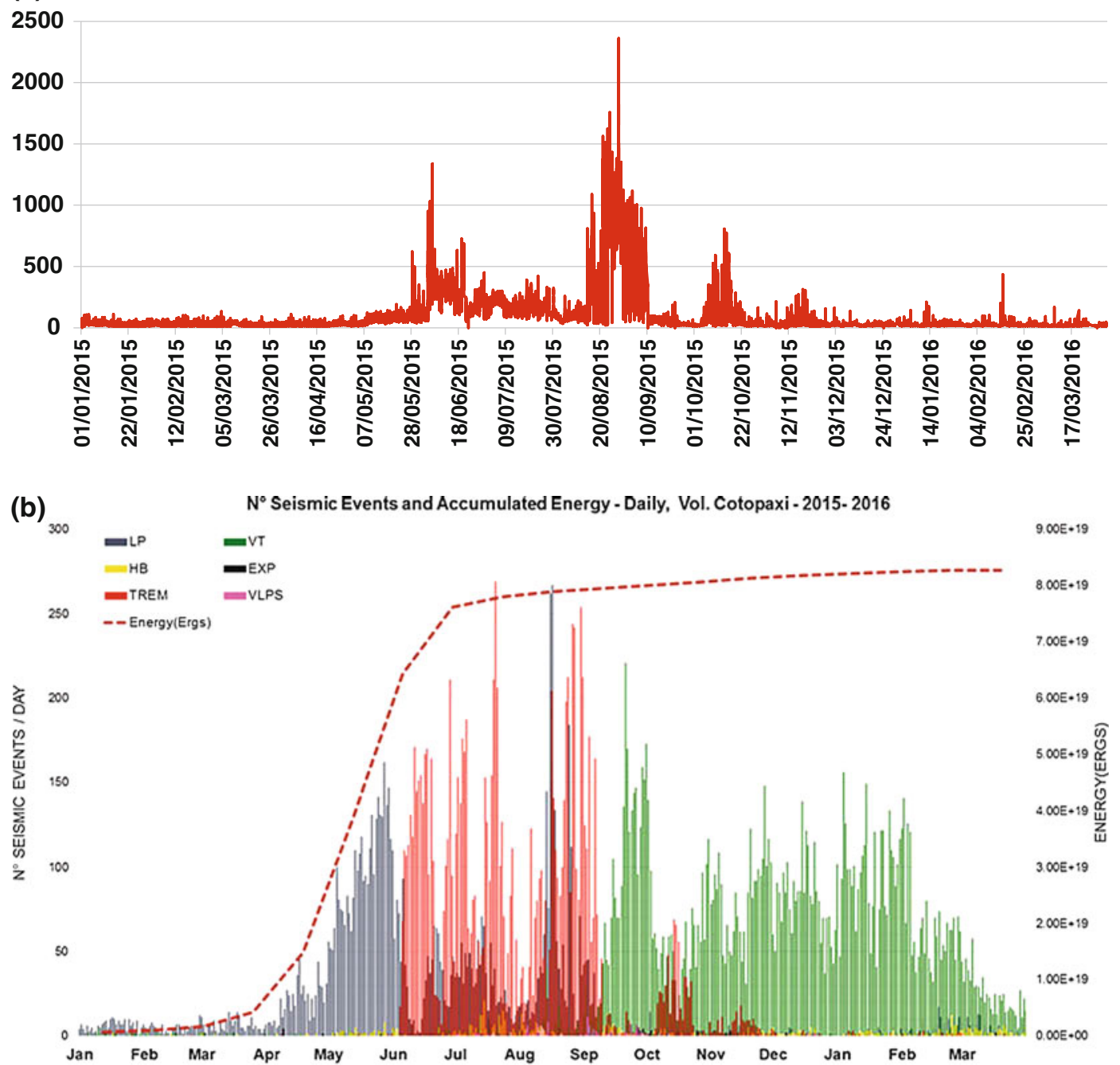

Fig. 3 a Plot showing RMS values of seismic data that has been segmented into $1 \mathrm{~min}$ windows and smoothed with a 31-point median filter. Of note is the calm period from January to April 2015, than a slight increase in seismic energy release in May. The increase in June is associated with greater emissions and strong tremor. A sharp decline in early August and later the notable increase in August and September represents the 14th of

a series of 5 explosions/energetic emissions on the 14th of August, which expulsed preexisting conduit plug material, ash and gases, but whose size did not surpass VEI $=1$. By late September 2015, activity mostly died back and RSAM
August explosions/emissions and subsequent ash emissions and emission tremor. Accumulated seismic energy values through the end of 2015 show a marked decline. b Number of daily seismic events versus accumulated seismic energy of these events. The acronyms for different seismic events are: $L P$ Long Period; $H B$ Hybrid; VT Volcano-tectonic; TREM High Frequency Emission Tremor; EXP Explosion; VLPs Very Long Period

values showed a decline except for brief hikes in October and in November, when light ashfalls occurred. By December 2015 nearly all monitoring parameters were down to background levels (Fig. 3a), except for a protracted 


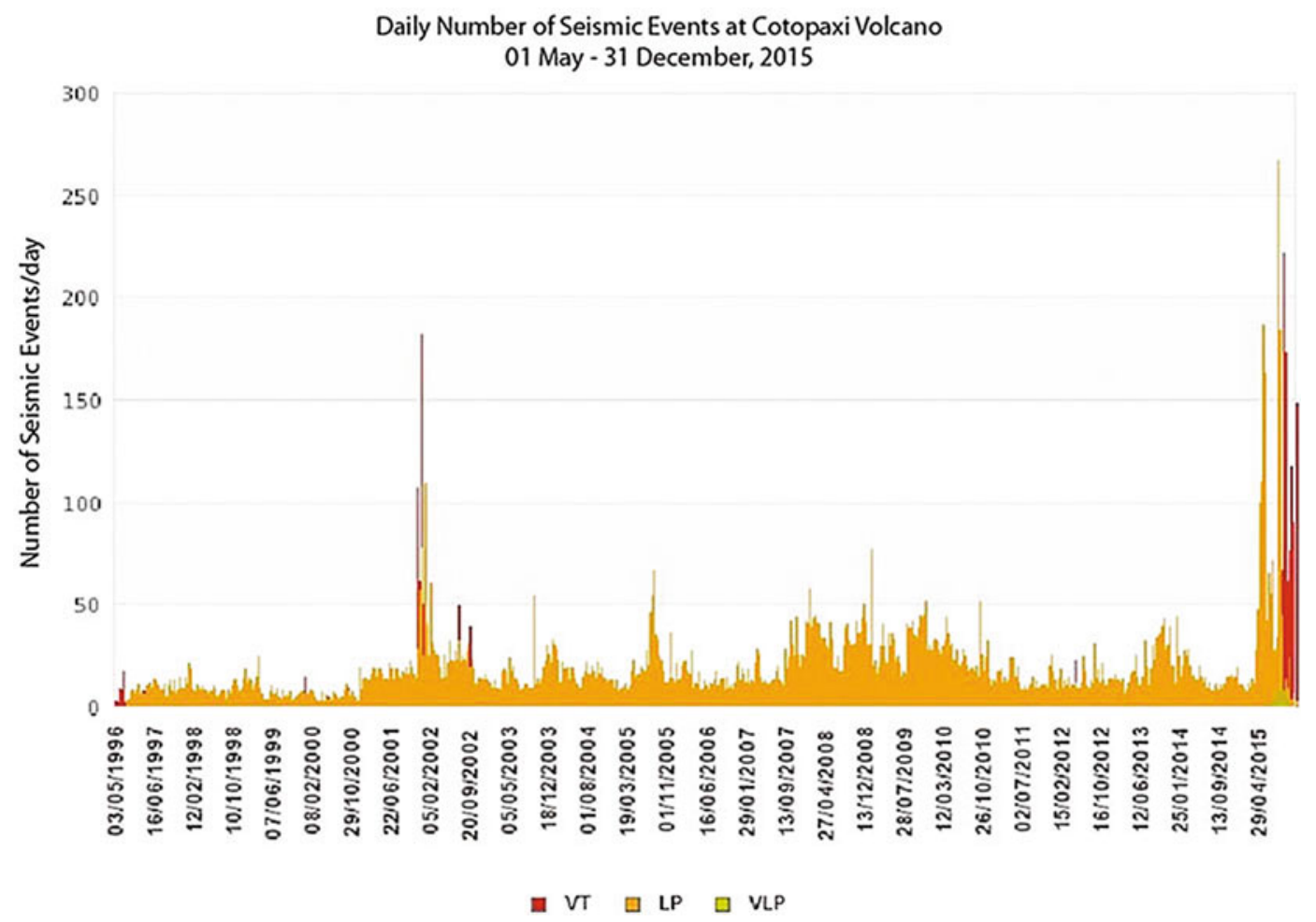

Fig. 4 Registry of VT and LP seismic events at Cotopaxi since May 1996 to 31 December, 2015. The 2001-2002 period was the only other period with a marked jump in seismic activity before the 2015 episode

volcano-tectonic (VT) seismic swarm that began on 10 September, 2015 and continued through March 2016, albeit displaying low levels of seismic energy release (Fig. 3b). This swarm produced nearly $15,000 \mathrm{VT}$ events.

\section{Geophysical Registry of Cotopaxi's Restlessness in 2015}

From 2002 to April, 2015, seismic registry of mostly long period (LP) seismic events averaged around 10 events/day. In April 2015 the monthly tally was about 630 earthquakes, then rose to 3000 events in May (Fig. 4), with a jump to about 180 events/day registered on 23 May (Fig. 4).

Of significance also was the notable increase in very long period seismic events (VLPs) recorded since late May 2015. VLPs are often interpreted to signify magma movement (Zobin
2012; Jousset et al. 2013; Maeda et al. 2015; Kumagai et al. 2010; Arias et al. 2015). VLP events are believed to be generated by volume changes and movements of magmatichydrothermal fluids (e.g., Chouet and Matoza 2013). Between June 2006 and October 2014, 106 confirmed VLP events were identified at Cotopaxi (Márquez 2012; Arias 2015). In 2015 Cotopaxi, VLPs rarely passed 11 events/day (Fig. 5), but commonly had magnitudes of 2-3. The recent VLP events that were located under the Cotopaxi's edifice, occurred in sectors of the volcano where VLP's had been previously located by Molina et al. (2008) (Fig. 6). The greatest number of VLPs, of the 114 located events, were registered during the third week of July up to the explosions on the 14th of August. While most were between 1 and 2 magnitude, some were greater than 2.5 (Fig. 5a). The relationship between the great number of LPs which started the awakening process at Cotopaxi and 
(a)
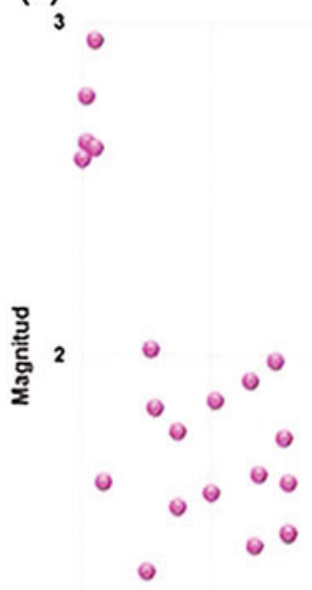

(b)

ฐ

\section{Magnitud vs Time of Located VLPs}

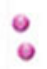

0

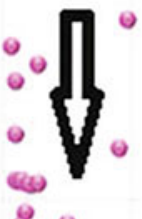

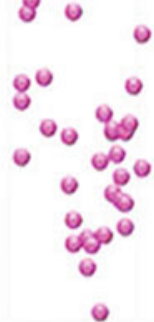

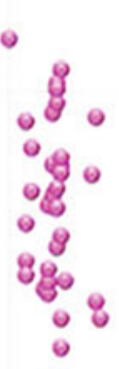

0 $\stackrel{5}{\gtrless}$ ஸे

ஸे ชั

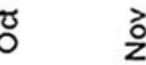

$\stackrel{\square}{\square}$

$\stackrel{\text { ำ }}{\rightarrow}$

윤

$N^{*}$ of events

located $=114$

(b)

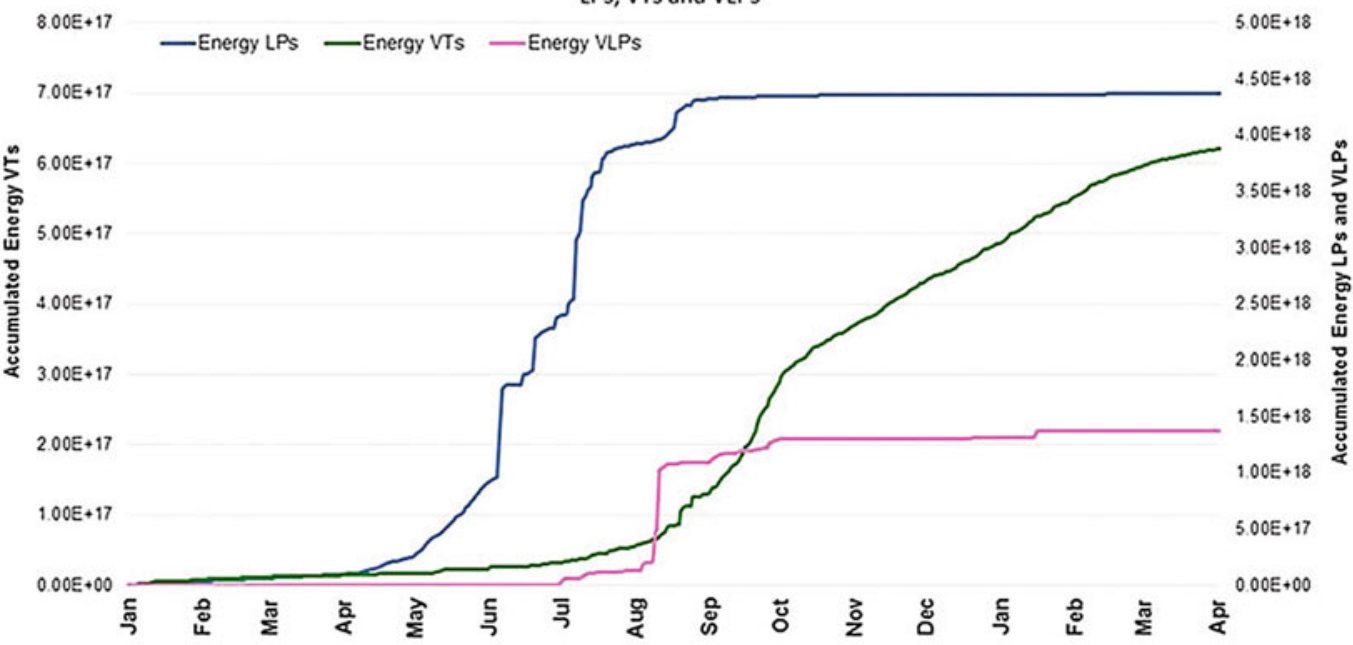

Fig. 5 a Occurrence of VLP events in 2015 at Cotopaxi. Black arrow represents 14 August hydromagmatic explosions. b Accumulated seismic energy from VTs, LPs and VLPs in 2015-2016 at Cotopaxi

afterwards the stalling out of these events to be followed immediately by the strong VLPs is another possible indicator of the precursory nature of this type of volcanic earthquake before the discrete eruptions on 14 August (Fig. 5b).
Most VLP events had frequencies between 0.1 and $1 \mathrm{~Hz}$ and had strong $\mathrm{P}$ and $\mathrm{S}$ waves, such as the example given for 04 August, 2015 which was located $3 \mathrm{~km}$ below summit on the NE flank of the volcano (Fig. 6). 


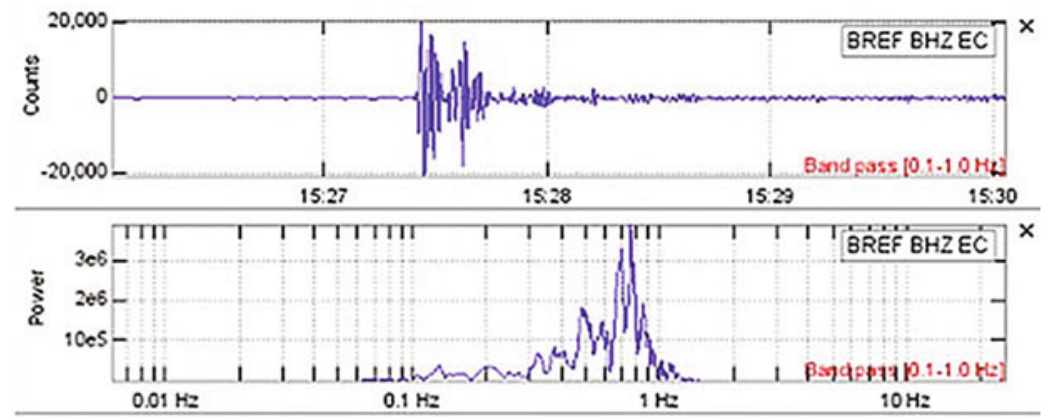

COTOPAXI, 201508041527, 20-160 s, 5-10 Hz
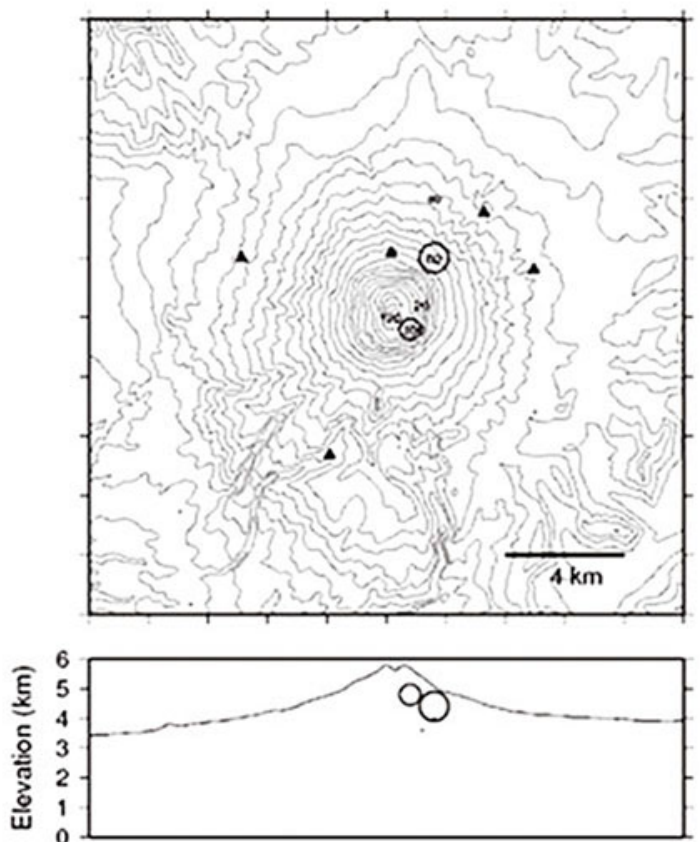

Elovation $(\mathrm{km})$

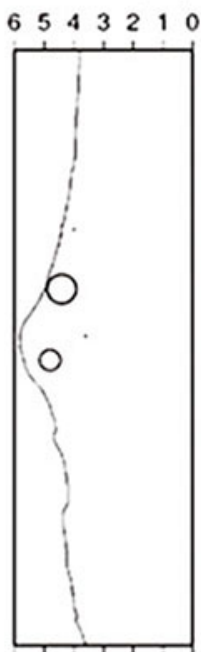

1.500 .05

Fig. 6 Waveform of VLP registered on 04 August, $201515 \mathrm{~h} 27$ GMT is one of the largest events registered at Cotopaxi (local magnitude 2.5) and was located $3 \mathrm{~km}$ beneath the crater on the NE flank

The locations of earthquakes (of all types) from January to December, 2015 were at two levels: at depths of about $3-5 \mathrm{~km}$ below the crater (Fig. 7a) and at a deeper level of 7-15 km below the crater. Most events were aligned with the conduit. However some distal VTs were registered about $15 \mathrm{~km}$ due north of the volcano (Fig. 7b) and were interpreted as fault slips due to stress transfer from the volcano (White and McCausland 2016). Distal VTs were also important in the reactivation of Pinatubo volcano (Harlow et al. 1996).
Overall, there was a marked increase of LP events from April to late May, followed by high frequency tremor episodes (Fig. 8) which lasted until the onset of high frequency tremor related to gas emissions and which became prominent from 04 June and lasted to the second week of August (represented by black bars), and could have been related to the boiling of the volcano's hydrothermal system, and coincided with the high water vapor and $\mathrm{SO}_{2}$ flux then emitting from the crater (Bernard et al. 2016). In Fig. 8, the VLPs that were important especially in July 


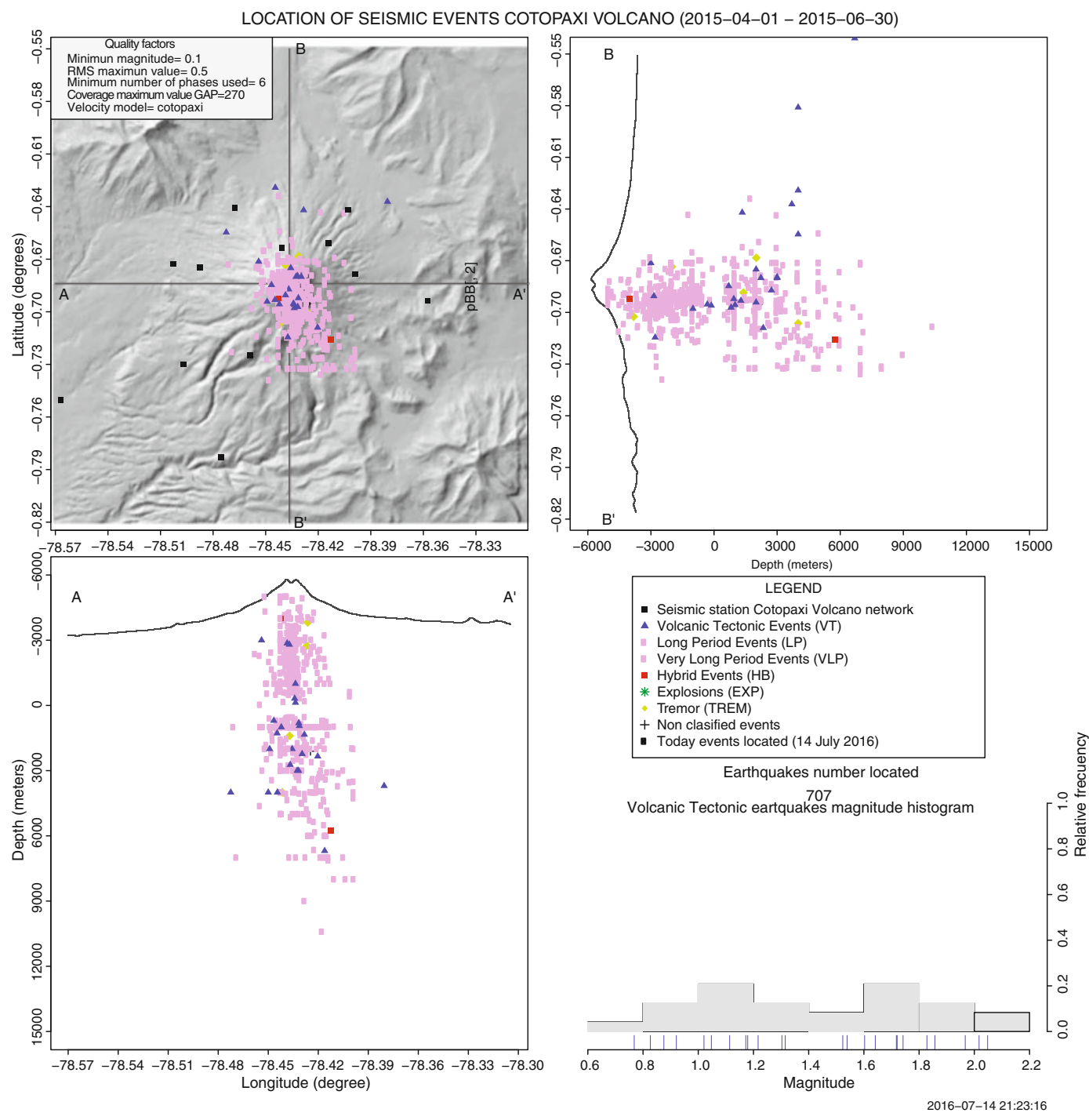

Fig. 7 Top-Locations of seismic events from a-01 April to 30 June, 2015 and Base-01 July to 31 August, 2015. Most are aligned with the conduit, however the SE flank is favored for harboring event locations

to mid-August are masked by this tremor signal, but can be observed in Fig. 3 and their accumulative energy levels are shown in Fig. 5.

The increase in $\mathrm{SO}_{2}$ gas emissions, rose to 3000 ton/day by the end of May with a clear $\mathrm{SO}_{2}$ signal progressively more notable through late May into June (Fig. 9) (Hidalgo et al. 2016). For example, on the 22nd-23rd of May odors of sulphur were very evident above the $5700 \mathrm{~m}$ level on the volcano's northern flank, as reported by Cotopaxi Park personnel.
GPS stations on the $\mathrm{W}$ and $\mathrm{S}$ flanks showed horizontal displacements of almost $16 \pm 0.5 \mathrm{~mm}$ toward the W and SW. GPS stations on the NE and E flanks showed displacements to the $\mathrm{N}$ at a reduced velocity (Fig. 10). The vertical component registered a maximum uplift of $15 \pm 2.3 \mathrm{~mm}$. The movement to the west could have been accentuated by the volcano's morphology, as the W flank is poorly buttressed and sits upon Inter-Andean Valley volcaniclastic fill. In comparison the east and northern part of the cone 


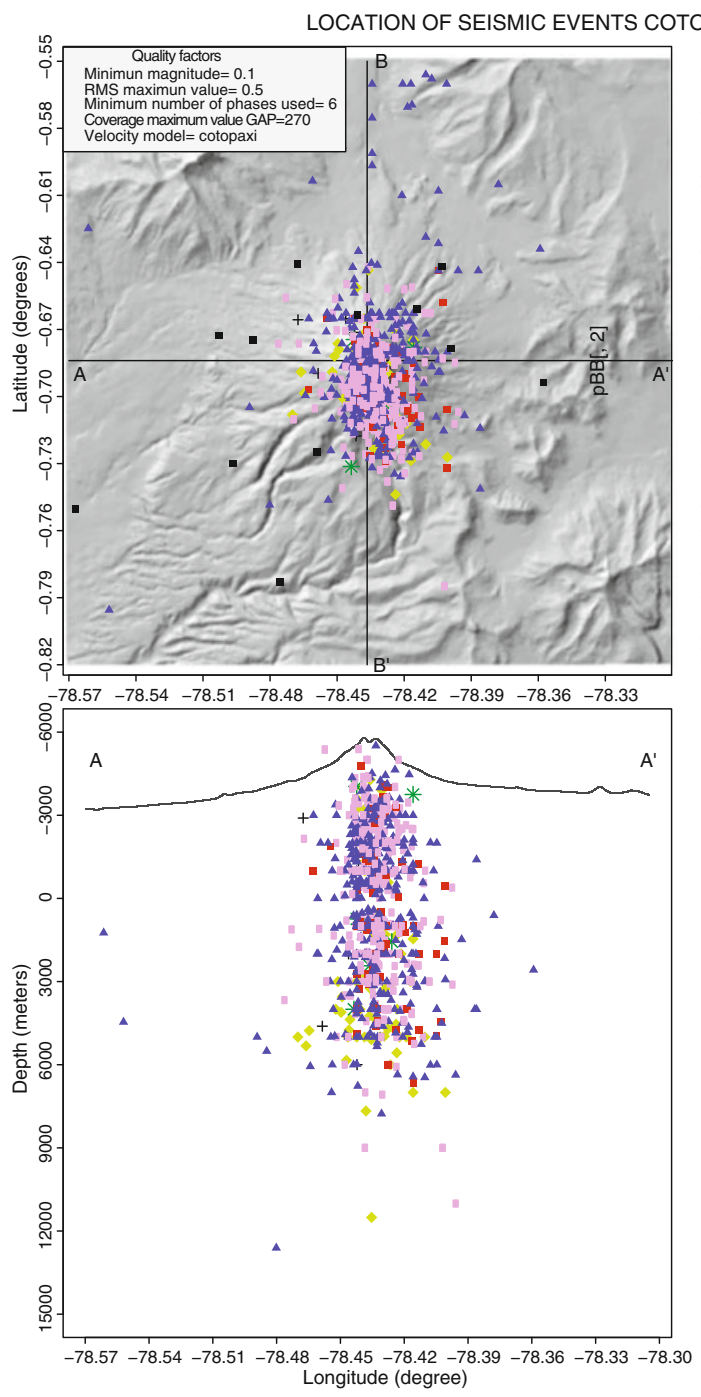

Fig. 7 (continued)

Fig. 8 a Comparative graph of LP seismic events (orange bars) and high frequency tremor (black bars) possibly related to the boiling of the hydrothermal system and gas movements from 01 April to 14 August, 2015. Ash and gas emission-related tremor (pink bars) abruptly

lies upon a thick lava package and basement crystalline metamorphic rock and may be more resistant to lateral movement. Data processing employed the program GAMIT/GLOBK (Herring et al. 2015) and used a local reference frame with respect to fixed South America (Nocquet et al. 2014. We also defined a long-term displacement model for each GPS site by estimating a trend and

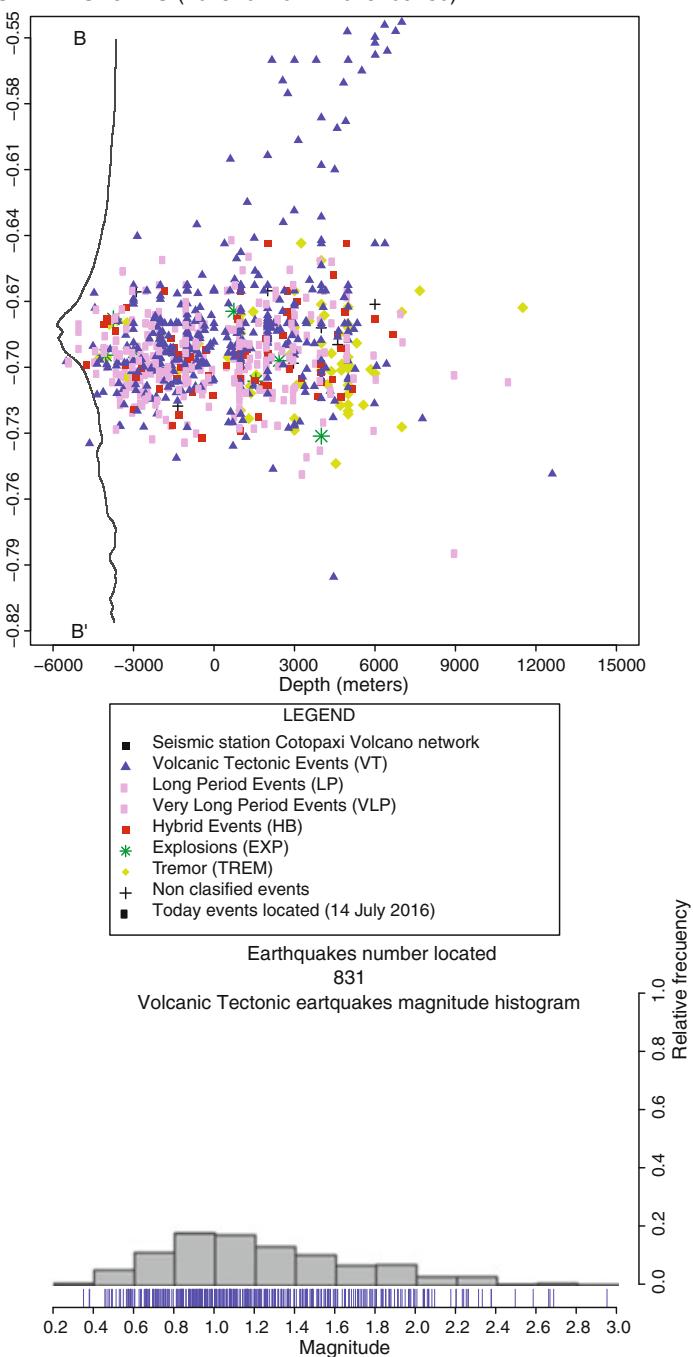

2016-07-14 21:28:41

began the second week of August, 2015, after the hydromagmatic explosions on the 14th. b Seismogram (11 June, 2015) of BREF station showing registry of spasmodic tremor related to internal fluid movements in the upper part of the edifice

annual and semi-annual components using all available data between 2008 and 2015. The transient displacements identified during the 2015 unrest period are with respect to this model. In a second step, we applied a common-mode filtering estimated from the average time series residuals for sites $\sim 50 \mathrm{~km}$ away from the volcano. Short-term repeatabilities are of the order of 1-2 $\mathrm{mm}$ on the 
(a)

300

250

200
150
100

50

0 hish

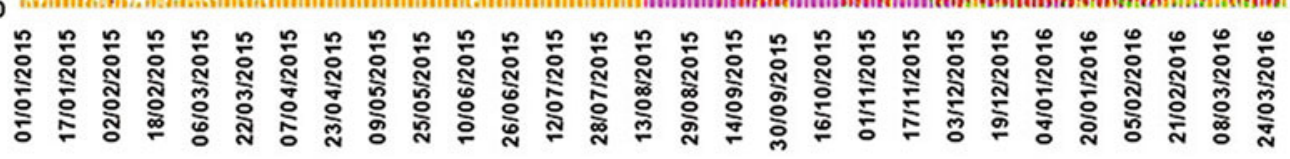

Number of Volcanic Events (Dally) - V. Cotopaxi

Between 01/01/2015 and 04/01/2016
The reference
station is VC1.

VT

ㄴP

EXPL

口 TREMI

(b)

EC.BREF..BHZ 2015.06-11

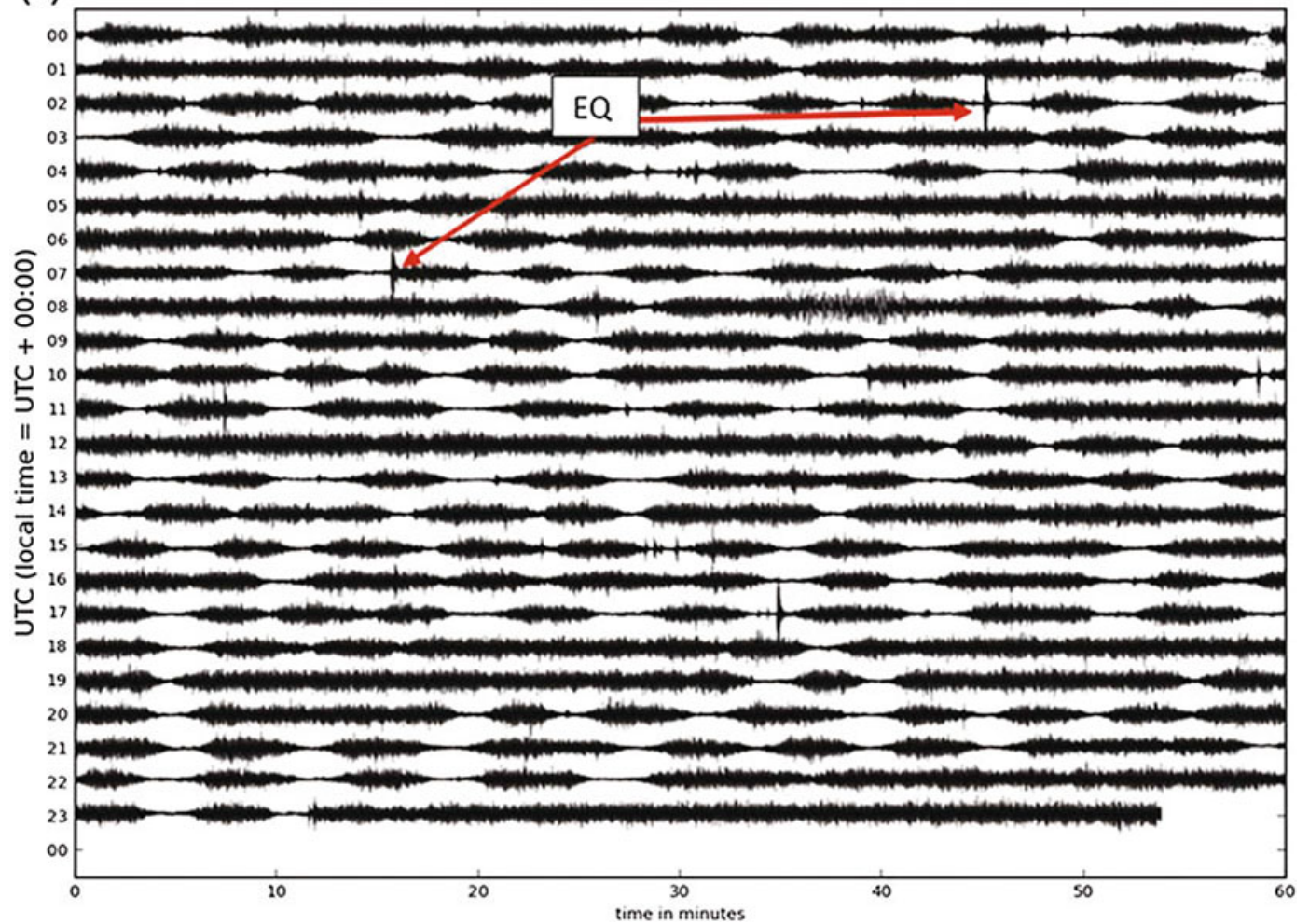


20,000

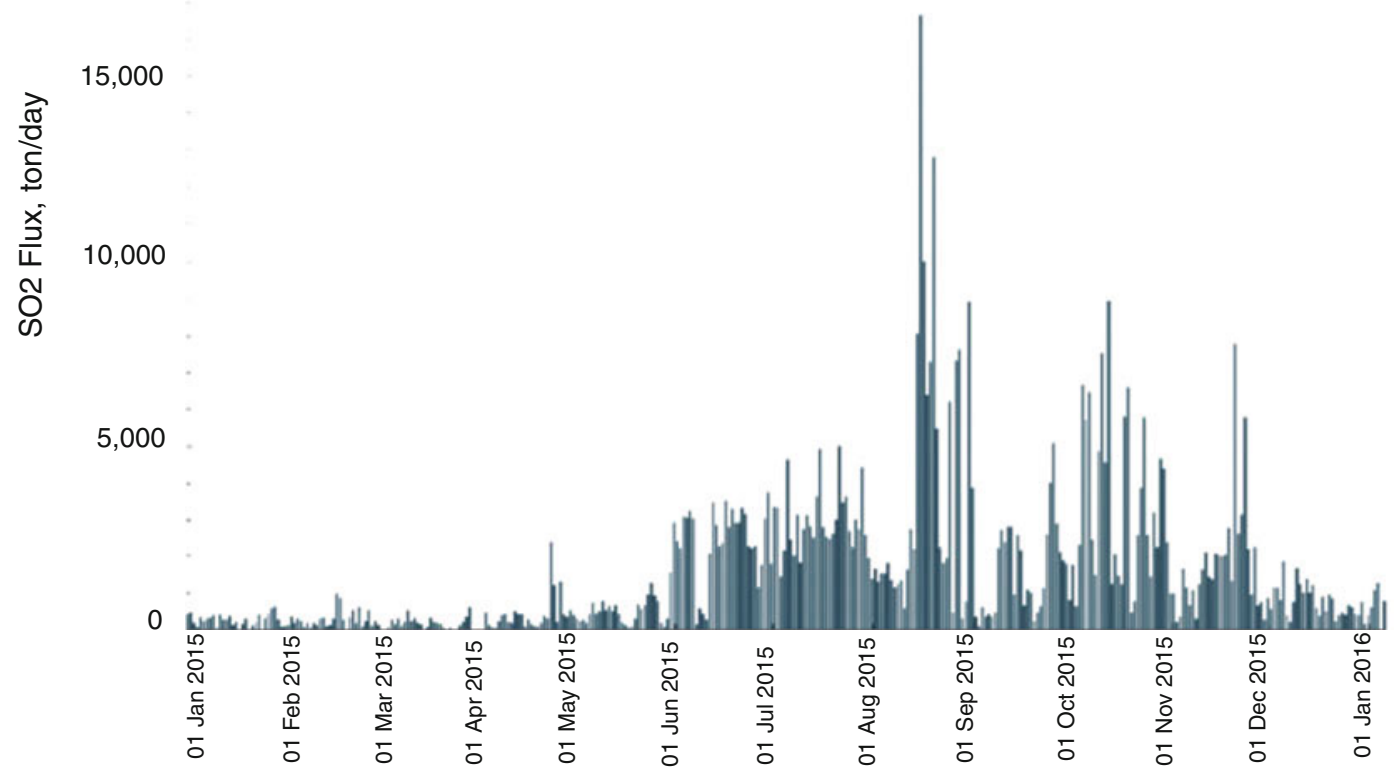

Fig. 9 Registry of $\mathrm{SO}_{2}$ values for Cotopaxi, January 2015 until 05 January 2016, with a significant increase in $\mathrm{SO}_{2}$ observed since early May. Data was processed daily using a single wind speed and direction obtained from the
NOAA and VAAC alerts. Graph included in Cotopaxi Special Report, No. 1, 2016: http://www.igepn.edu.ec/ cotopaxi/informes-cotopaxi/coto-especiales/coto-e-2016/ 14074-informe-especial-cotopaxi-n-01/file horizontal components and $3 \mathrm{~mm}$ on the vertical component, enabling us to extract the small GPS signal observed during the unrest period.

Due to the westward movement on the GPS station PSTO, which is $22 \mathrm{~km} \mathrm{~W}$ of the crater (Fig. 10), we surmised that the source was deep. Subsequent modeling of the data suggested a source of about $24 \mathrm{~km}$ deep located under the SE flank with a volume of $42 \pm 26 \mathrm{Mm}^{3}$ (Mothes et al. 2016b). Nonetheless, as mentioned in Sect. 3.1, analysis of the erupted ash suggests that the magma source is shallow, as least for the initial small volume that was emitted.

Data from a tiltmeter (VC1G on Fig. 2) installed in a thick lava package and located $6 \mathrm{~km} \mathrm{NE}$ of the crater, showed a strong inflationary pattern that had started in April, 2015 on both axis. This tilt anomaly coincided with the notable increase in seismicity (Mothes et al. 2016b). Generally, when LP seismicity and tremor were both strong, a positive tilt signal predominated.

\section{Hydromagmatic Explosions/Strong Emissions of 14 August, 2015}

On the evening of 13 August, a swarm of VT and LP seismic events was registered between $20 \mathrm{~h} 03$ (GMT) on the 13th to 08h55 (GMT) in the early hours of the 14th, antecedent of the explosion events (Fig. 11). At 09h02, 09h07 and later at $15 \mathrm{~h} 25,18 \mathrm{~h} 45$ and $19 \mathrm{~h} 29$ (UT) five small explosions/strong emissions were registered at Cotopaxi which served to unblock the conduit and led to ejection of degassed altered conduit plug material and scarce juvenile components. Although infrasound from these explosions did not exceed 4 Pascals $(\mathrm{Pa})$ at stations located approximately $6 \mathrm{~km}$ from the vent, the first two 


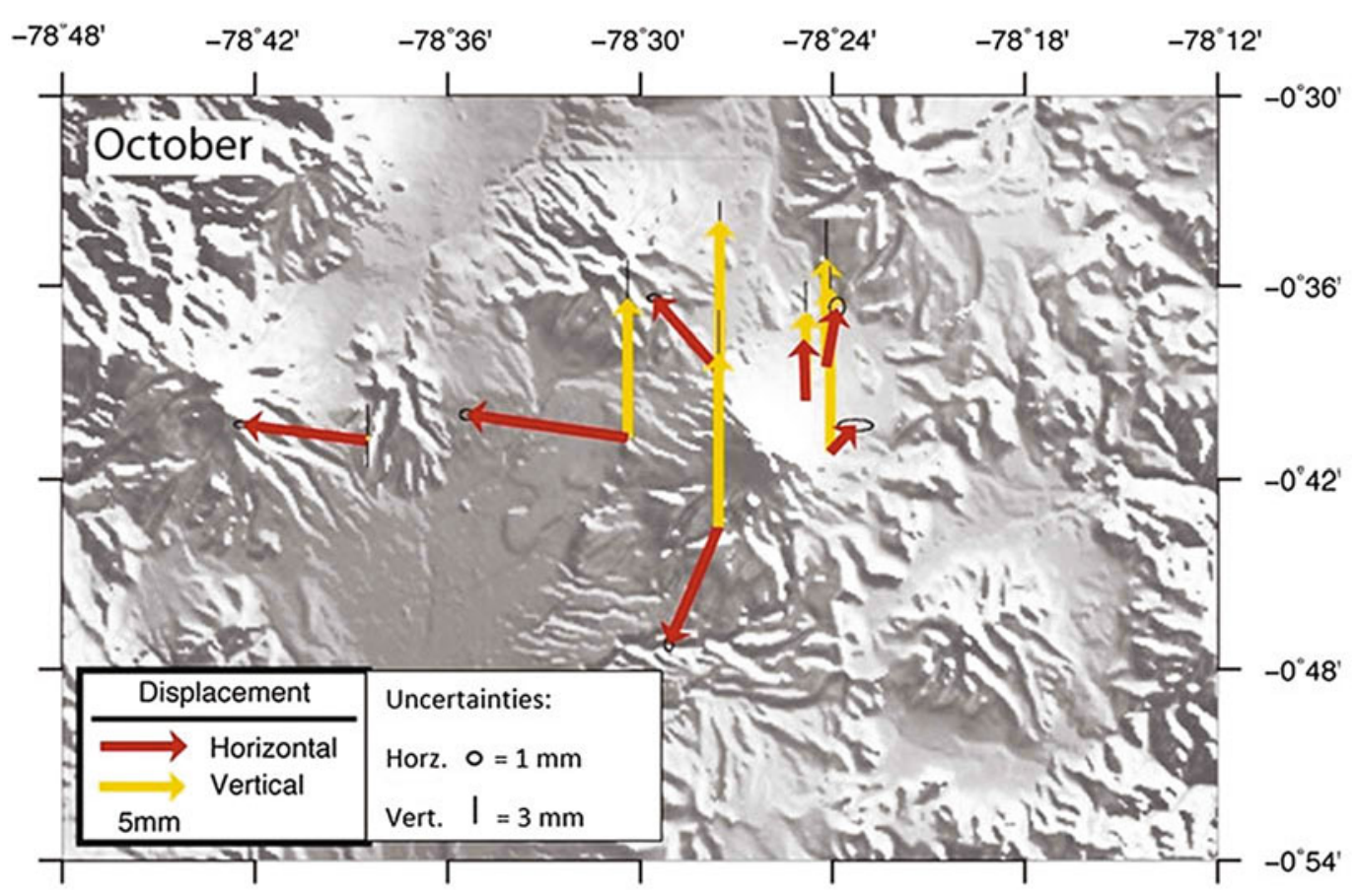

Fig. 10 GPS vectors for stations around Cotopaxi's cone and one to the west for October, 2015. Displacements are expressed with respect to the North Andean Silver and

explosions were heard by climbers in the Refuge on Cotopaxi's north flank, where lapilli-size fallout reached the Cotopaxi Refuge.

Two months earlier public and authorities had been forewarned in the special IGEPN reports (No. 3 and 4) that phreatic explosions would be a likely phenomenon in precursory eruptive activity (http://www.igepn.edu.ec/cotopaxi/informescotopaxi/coto-especiales/coto-e-2015/12990informe-especial-cotopaxi-11-06-2015/file).

With these explosions the eruption column at $15 \mathrm{~h} 25$ rose to $9 \mathrm{~km}$ above the crater rim and was clearly visible from the SW (Fig. 12a, b). Infrasound values of the explosions were less than $10 \mathrm{~Pa}$ at station BNAS $(5 \mathrm{~km}$ from the crater), but the seismic source amplitudes of the tremor associated with the first two explosions were greater than those of most Cotopaxi LP events and also of some explosions registered at Tungurahua volcano (Kumagai et al. 2015). The initial explosions had evidence of water involvement. In previous weeks a small lake was observed in the crater's bottom; this was represent the comparison of GPS data collected from 01 January to 01 October, 2015 at the 7 station Cotopaxi CGPS network

totally evacuated by the explosions. Observers also reported that the fallout had a "wet aspect" and many of the fragments were agglutinated by a fine clay-size patina. The eruption is categorized as hydromagmatic, since the rapid interaction with water caused overpressures beneath the plug, raising lithostatic pressures that overcame the capacity of the altered conduit plug rock. After these main vent-opening events the presence of hydrothermally altered material gradually waned and possible juvenile material became more prevalent (Gaunt et al. 2016).

The ash emissions from this first activity covered agricultural lands to the NW and $\mathrm{W}$ of the volcano with $\mathrm{a} \leq 1 \mathrm{~mm}$ thick dusting of altered silt to sand lithic grit and crystals (Fig. 13a) and caused poor visibility along major highways that enter Quito from the south. This ash emission mantled over $500 \mathrm{~km}^{2}$ with more than $80 \mathrm{gr} / \mathrm{m}^{2}$ and amounted to a volume of $118,000 \mathrm{~m}^{3}$, keeping it within the range of a VEI = 1 (Bernard et al. 2016) (Fig. 13b). 


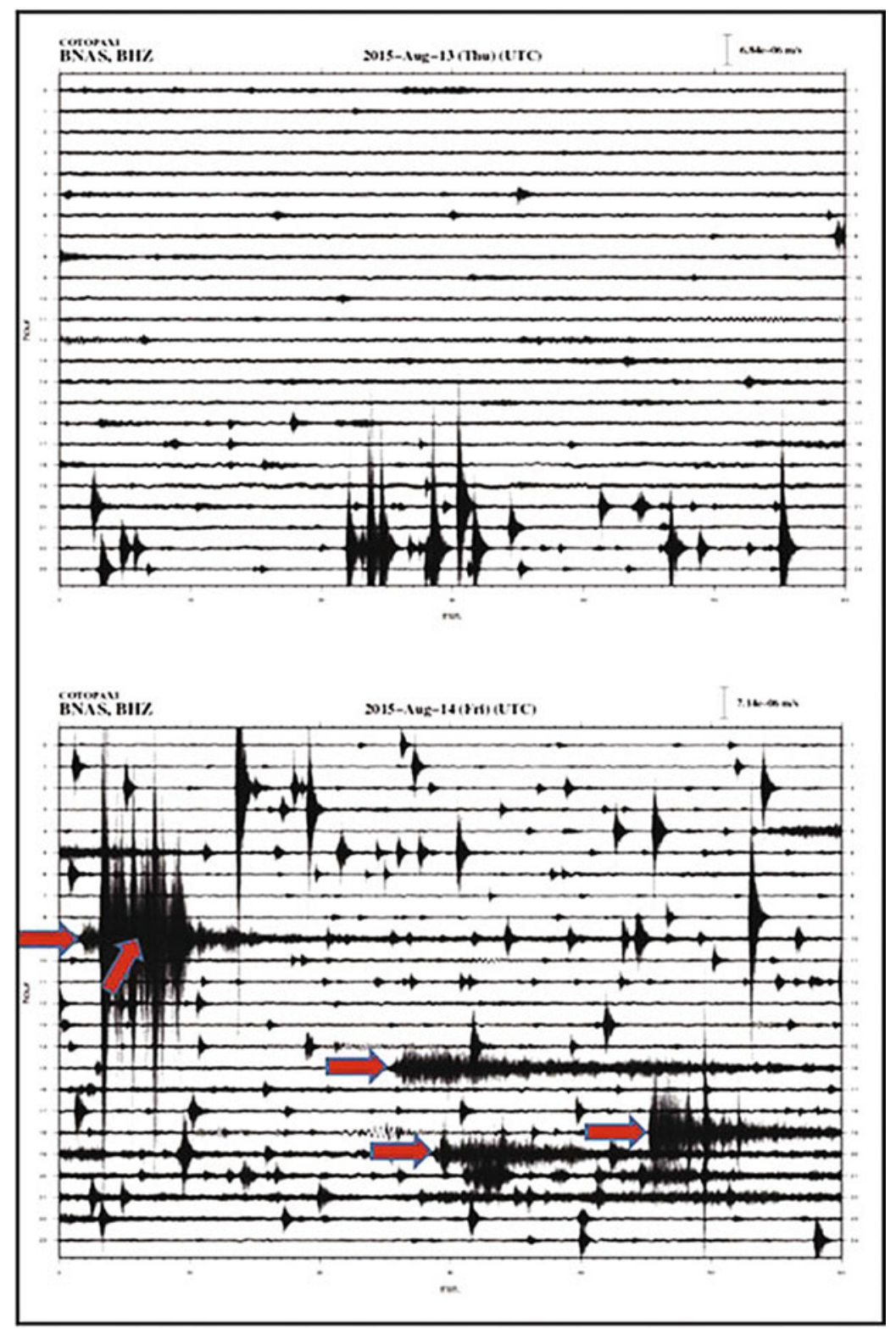

Fig. 11 Registry of VT-LP seismic swarm which begin late 13 August, 2015 and was followed by the 5 small explosions/strong emissions on 14 August, all indicated with red arrows. Seismograms are of the IGEPN's monitoring network

\section{Post 14 August, 2015: Open Conduit Degassing and Ash Emissions}

Ashfalls were prevalent towards the N and NW after 14 August into October and became scarce in late November (Fig. 14). A common scene was that of the ash and gas plume cascading down the $\mathrm{W}$ flank, with only the initial pulse rising to $<1 \mathrm{~km}$ upon emitting from the crater (Fig. 14).

Emission tremor of varying amplitudes accompanied the ash emissions and permitted IGEPN monitoring scientists to forecast if the 


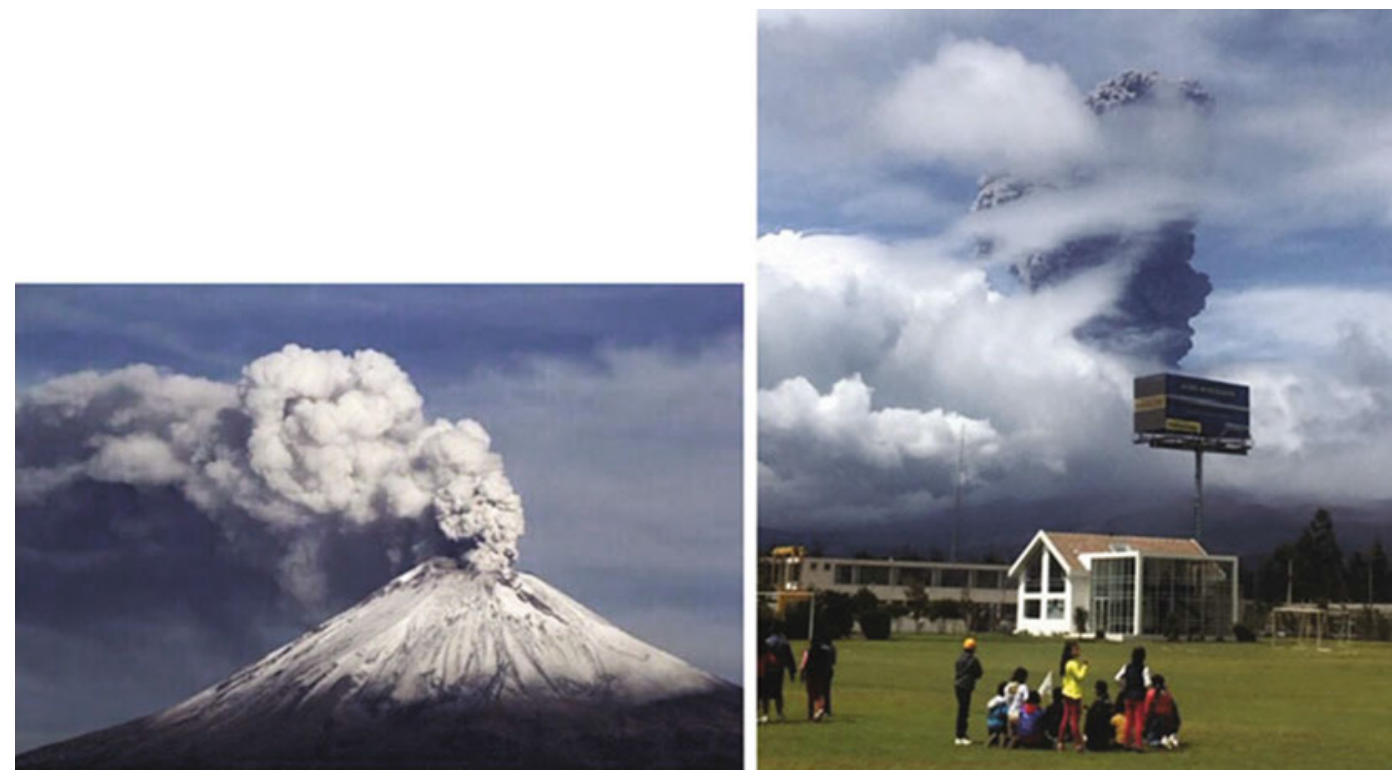

Fig. 12 Left Cotopaxi's 14 August, continuing emission - view of the volcano from SW at 14h10UT. Photo E. Pinajota, IGEPN. Right- The 15h25UT strong emission produced a column that ascended $6-8 \mathrm{~km}$ above the summit. Photo by Santiago Tapia, at the Novacero company grounds, $20 \mathrm{SW}$ of the volcano
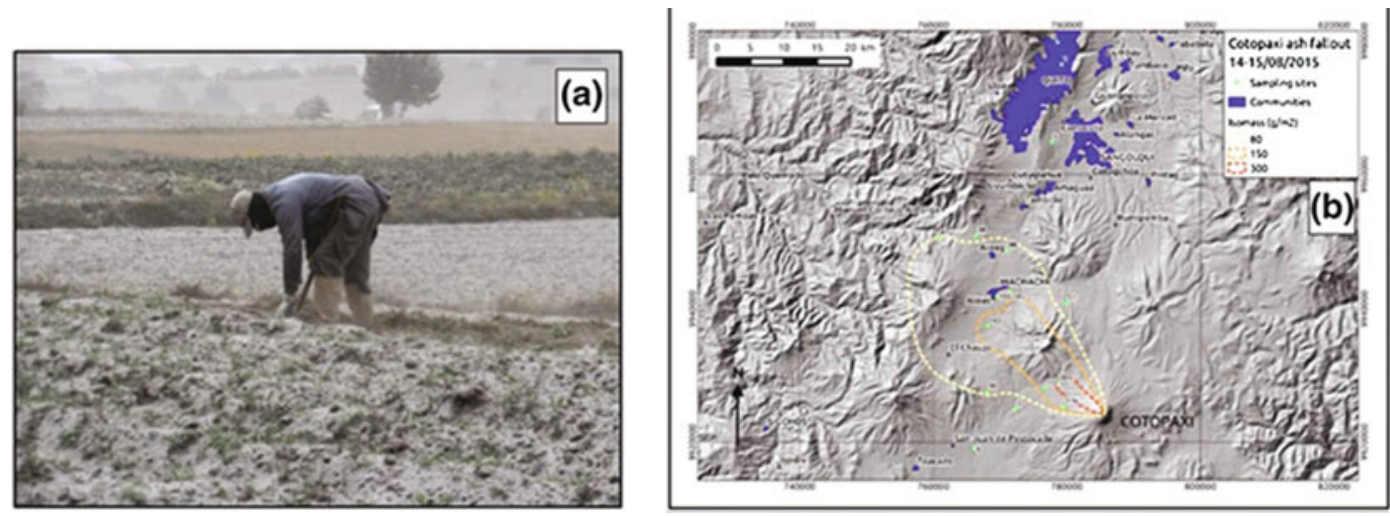

Fig. 13 a Ashfall from 01 September emissions accumulated in cultivated fields near El Chaupi town. b Ash fallout map associated with the eruptive activity of Cotopaxi on the 14th-15th of August, 2015. Map projection WGS 84, coordinates in UTMs. Values expressed in isomass of grams $/ \mathrm{m}^{2}$. Source Bernard et al. (2016)

rate of ash falls was increasing during frequent foggy, overcast conditions (Bernard et al. 2016). On the 14th of August, after the explosions, $\mathrm{SO}_{2}$ levels reached 16,400 ton/day as registered by the satellite sensor OMI (http://so2.gsfc.nasa. gov/pix/daily/ixxxza/loopall3.php?yr=15\&mo= $08 \& d y=15 \& b n=e c u a d o r) \quad$ (Fig. 15). Subsequently, $\mathrm{SO}_{2}$ levels were particularly high on the 15th and 24th of August, when OMI measurements gave readings of 6500 and 6600 ton/day, respectively.

In early September ash columns still rose to over three kilometers height above the vent and carried fine ash particles to cities on the piedmont of the coastal plain, such as Santo Domingo de los Colorados, located $120 \mathrm{~km} \mathrm{~W}$ of the volcano, 

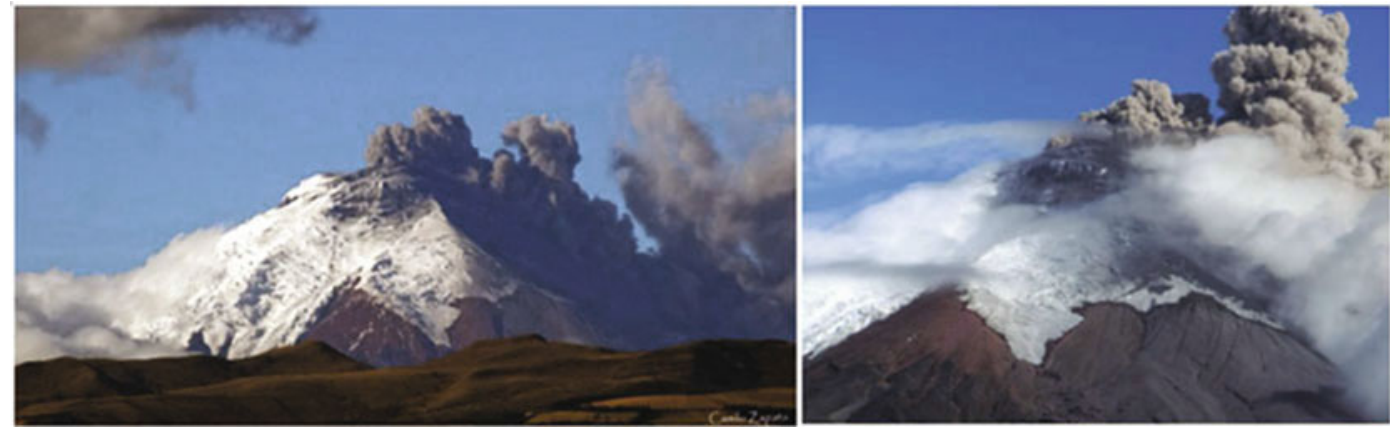

Fig. 14 Left Photo with view toward south taken from Autopista Ruminahui (SE of Quito) on 20 August. PhotoC. Zapata- EPN. Right Photo taken on the 23rd of August,
2015, from the north side of Cotopaxi. A low gas and ash column trending to the NW is observed. Photo P. Mothes, IGEPN essentially situated under the red swath trending $\mathrm{W}$ in Fig. 15.

Ashfall was still prevalent in mid-October, but had all but terminated the third week of November where it was seen W-NW of the volcano. VAAC Washington again reported suspended fine ash above Santo Domingo as well as in Los Rios province to the SW. The ash column generally rose to only 1 and $3 \mathrm{~km}$ above the summit and had a velocity between 6 and $10 \mathrm{~m} / \mathrm{s}$ and lasted about one week. Fieldwork permitted the estimation of a mass and volume total of $3.49 \times 10^{7} \mathrm{~kg}\left(22,100 \mathrm{~m}^{3}\right)$ for this late, waning period (Bernard et al. 2016). The total ashfall dense rock equivalent (DRE) volume for the entire eruption was calculated in $0.5 \mathrm{Mm}^{3}$ (Bernard et al. 2016).

\section{Ash Componentry}

Analysis of ash beneath both binocular and scanning electron microscope showed clearly that there was an evolution in ash componentry from the eruption's beginning on 14 August and later. The first ash from 14 August had more hydrothermal lithics (pyrite, scoria with vesicles filled with altered material and hydrothermal quartz). As the eruptions progressed we saw an increase in more fresh magmatic components, such as free crystals, glass particles with low vesicularity and a high percentage of microlites, which implied low magma ascent rates and stiffening of magma in the upper part of the column (Gaunt et al. 2016).

Ashes collected on the 20th of October, had a high concentration of dense microcrystalline material. Although there is evidence of few vesiculated clasts (diktytaxitic texture); about $65 \%$ of the ash is considered possibly juvenile. Gaunt et al. (2016) suggest that the origin of the ash is the top of a degassed magma column which had ascended from about $3 \mathrm{~km}$ below the crater.

\section{Seismicity}

For most of the post explosive period after mid-August, seismic hypocenters still remained located at the two depths mentioned above (Fig. 7). Most relevant was the sporadic occurrence of VT events with magnitudes of 3 or greater that occurred. Sometimes spasmodic tremor was registered and continued for hours, as for example, that registered on 02 September, 2015.

Starting on 10 September, a swarm of VT seismic events kicked in with a rate of approximately 100 events/day and a daily registry of coeval small internal explosions which has associated infrasound signatures, (shown in green color in Fig. 16). This swarm lasted past the New Year, but the overall seismic energy release was low (Figs. 3b and 5). 


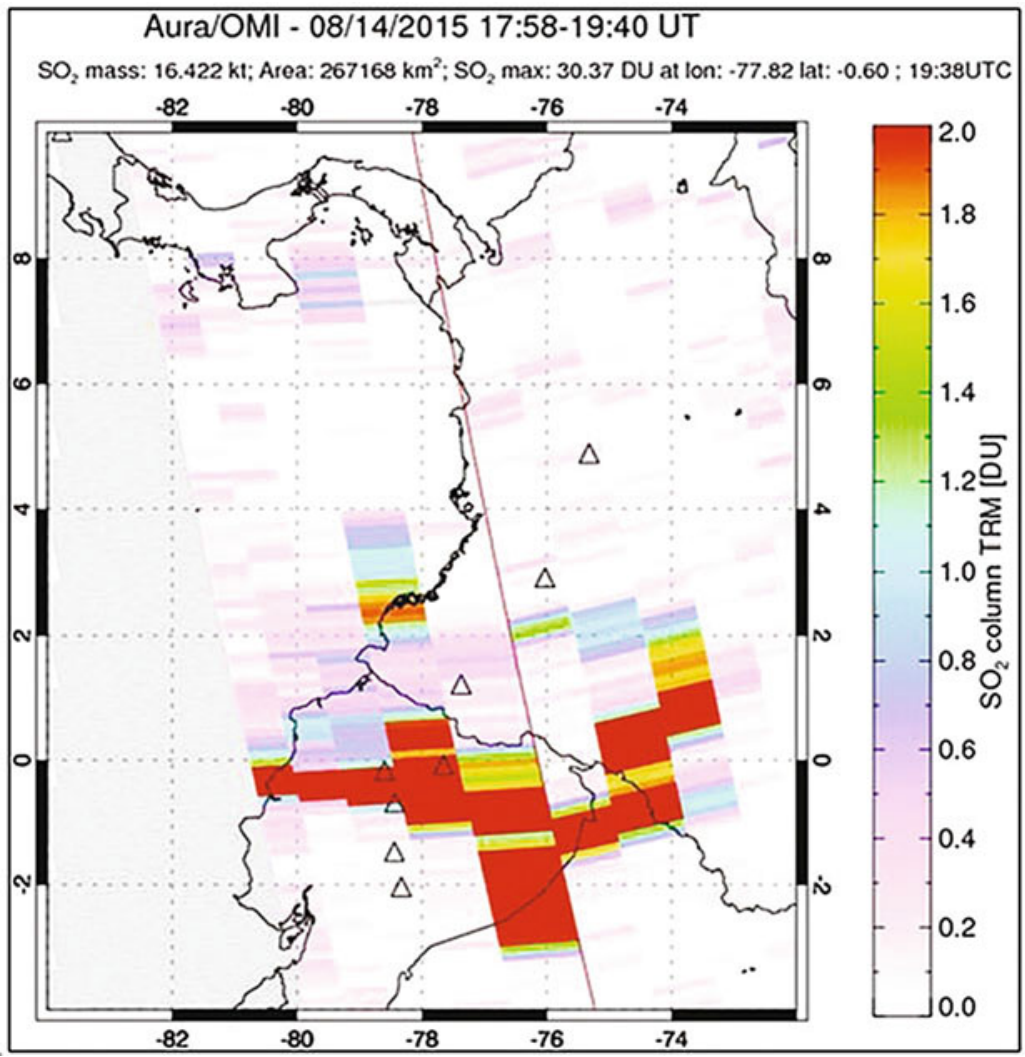

Fig. 15 Registry of $\mathrm{SO}_{2}$ (16,400 ton/day) from satellite as detected by the OMI sensor on the 14th of August, 2015

\section{Visual Observations and Secondary Effects}

Thermal images (August/2015) showed the presence of new thermal anomalies $\left(\sim 15{ }^{\circ} \mathrm{C}\right)$ inside the crevices on the $\mathrm{N}$ side glaciers, at the same time fumarolic gases were observed coming out from those fractures. The highest temperature obtained was about $200{ }^{\circ} \mathrm{C}$ (Fig. 17) from gases ascending the crater.

On September 3, water emerging from the basal fronts on the northern glaciers was clearly observed, and countless new crevices in the majority of glacier ends and on the upper flanks were evident. All this led to the conclusion that an abnormal process was producing increased melting of the glaciers. Starting in mid September it was possible to observe the presence of small secondary lahars descending several streams and we estimated that many of them were due to increased glacier melting.

Orthophotos made on August 18 and then again on October 8 , show a decrease of about $0.49 \mathrm{~km}^{2}$ of the area covered by glaciers. This represents a very high rate of glacier melting, not explained exclusively by climate change (Cáceres et al. 2016).

We estimate that small volumes of magma reached surface levels in the volcano conduits causing increased circulation of hot fluids inside the edifice, apparently reaching the basal area of the glaciers and producing increased melting. It is necessary to further investigate the hazard due to instability in the melting glaciers and their eventual collapse that could lead to greater secondary lahars. Numerical modeling by 


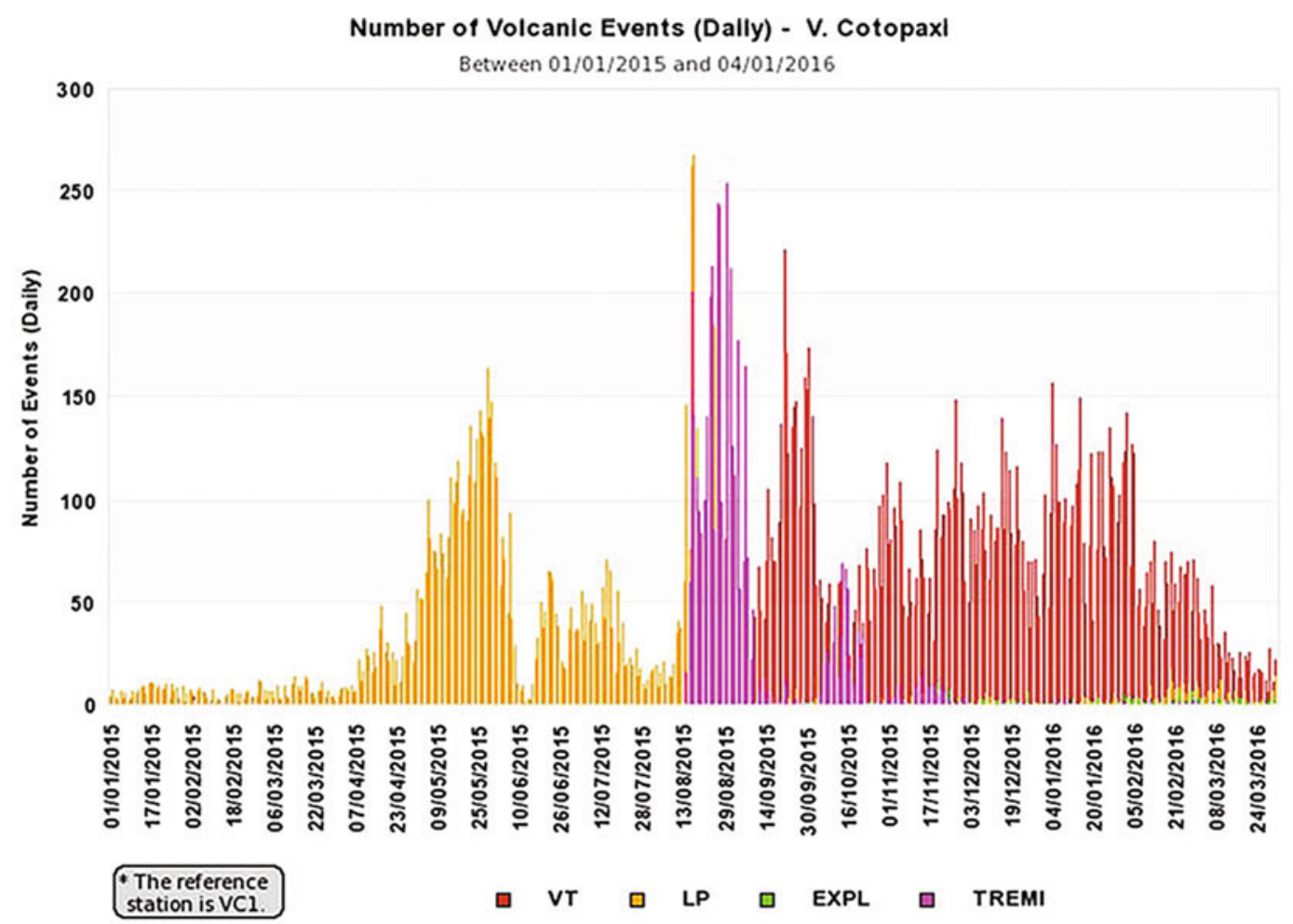

Fig. 16 Registry of overall seismicity at Cotopaxi volcano from 01 January 2015 to 01 April, 2016. Most notable is the presence of LP earthquakes in the first semester of 2015 , later followed by emission tremor and

Hemmings et al. (2016) has shown the importance of hyrdrothermal perturbations at Cotopaxi in generating watery flows.

Incandescence was also occasionally observed on cold still nights with a thermal camera or by simple vision. These events were considered to have been caused by pulses of hot gases.

The glacier around the crater, on the $\mathrm{W}$ and $\mathrm{N}$ flanks, became partially covered by ash. This coating of dark ash decreased the glacier albedo and consequently increased the absorption of solar rays. Therefore expedite melting of the glacier tongues increased, leaving obvious melt water channels issuing from the glaciers' base.

As a result of the afternoon melting by insolation and perhaps also by higher temperatures of the rock beneath the glaciers, runoff increased, especially off the W flank glaciers finally with the advent and continuance of frequent VT seismic events with accompanying internal explosions that had no superficial manifestation, except infrasound registry

and there were frequent small secondary lahars. Those lahars that have been especially associated with rain storms obtained the highest discharges - on the order of $10-30 \mathrm{~m}^{3} / \mathrm{sec}$ (D. Andrade-IGEPN, Pers, Comm, 2015). The Agualongo channel, on Cotopaxi's W side was frequently flooded by lahars and on three occasions they covered partially the main road giving access to the volcano.

\section{Interpretation and Model}

As shown in Fig. 16, LP events gradually increased starting in April, 2015, beginning with small magnitudes and low energy levels (Fig. 3). We interpret the LPs to imply fluid movement occurring at 10-12 km below the crater and then up to shallower levels (Fig. 7). There were only 


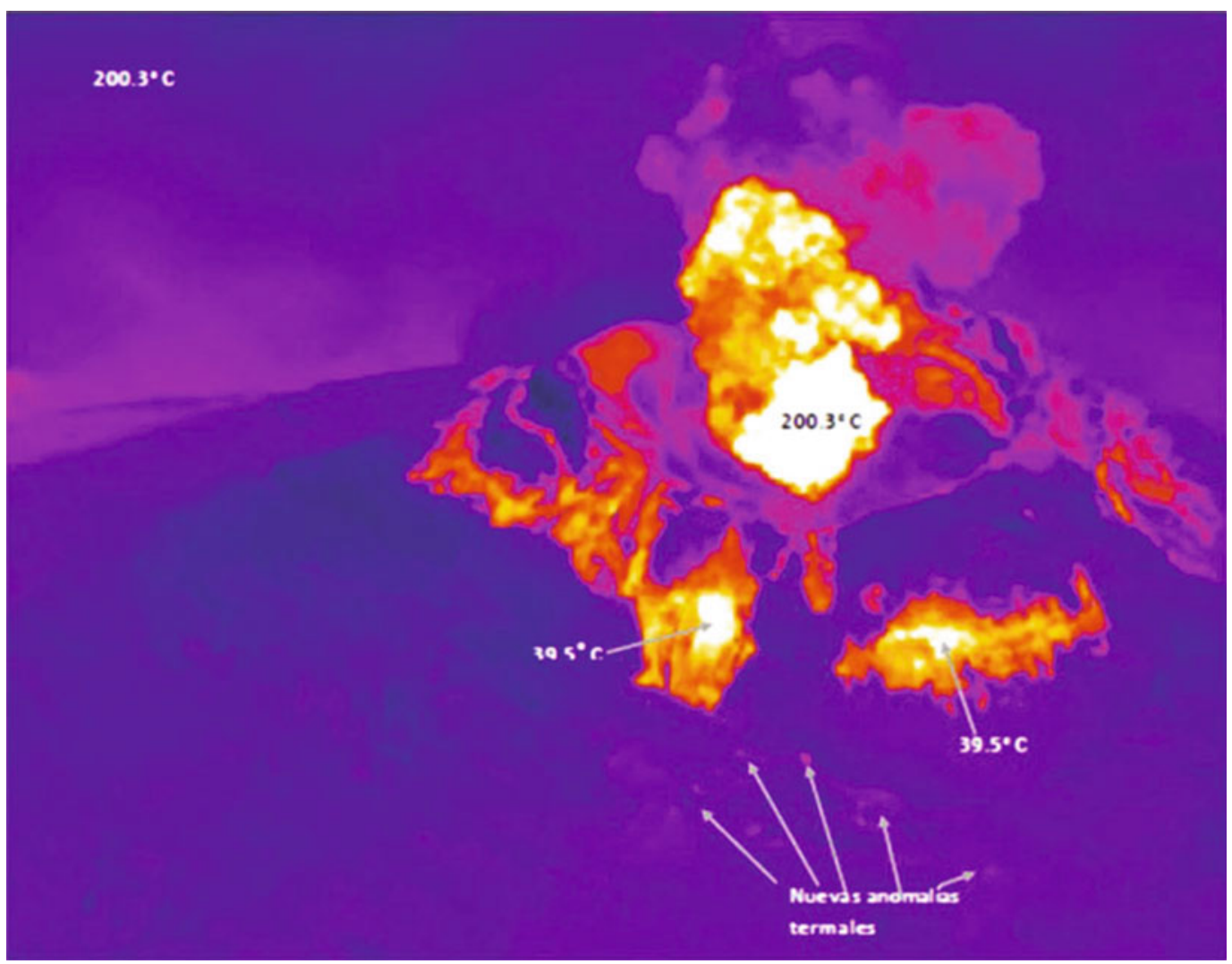

Fig. 17 Thermal image taken on 03 September, 2015 looking toward the SE sector of the upper cone. The infrared camera detected temperatures of $200{ }^{\circ} \mathrm{C}$ associated with emission from the crater and lower temperatures

scarce VTs that occurred in concert with the LPs. In late May VLPs were registered (Fig. 5) and were interpreted to be possible mass magma transport processes as reported by Arias et al. (2015). Often VLPs are identified as eruption precursors, e.g. at Redoubt (Power et al. 2012), for example. In hindsight, vigorous VLPs were also registered in 2009-2010 at Cotopaxi and correlated with recoverable deformation patterns at borehole tilt stations (Mothes et al. 2010), but did not result in an extended seismic crisis or magmatic activity on the surface.

Nonetheless, LP and VLP events registered in April-August, 2015 were apparently responding to a slow ascent of a small magma slug and associated fluids and in April 2015 deformation recorded by tilt and GPS stations began almost synchronically with the jump in LP seismicity, from fractures below the summit rim. Photo P. Ramón, IGEPN. Source http://www.igepn.edu.ec/cotopaxi/ informes-cotopaxi/coto-especiales/coto-e-2015/13529-

informe-especial-no-14/file

implying that there may already have been magma ascent from a deeper depth to a shallower reservoir in order to show changes on the most proximal tiltmeters. The GPS stations begin to show minor displacements at the same time, particularly on the W-SW flank, where no strong evidence was detected in seismicity, but to the contrary seismicity was concentrated more on the E-SE flanks (Fig. 7). In sum, we registered both shallow and deep seismic activity. A leading hypothesis for this pattern likely was the interaction between fluids being released by a deep-seated source, say at $24 \mathrm{~km}$ depth as proposed in our geodetic model. These fluids ascended and perturbed a preexisting shallow-seated source, which may be the magmatic remnant that drove the 2001-2002 unrest reported by Hickey et al. (2015). 
With more new magma in Cotopaxi's system, $\mathrm{SO}_{2}$ output became prevalent in mid-May, one month after the hike in seismicity. Background $\mathrm{SO}_{2}$ levels of $<500$ ton/day were surpassed and rose to over 3000 ton/day. The strong onset of bands of tremor about the 1st of June, were conjectured to be related to continual fluid movement within the edifice and perhaps to the boiling of the hydrothermal system and was a signal that more overall heat was circulating within the edifice.

Along with the rise in $\mathrm{SO}_{2}$ there was also a trend in production of more VLP's since 114 of these events were registered between May and mid-August, 2015. Of great significance is that the largest VLPs were registered in the last 3 weeks before the hydromagmatic explosions. Afterwards too there were infrequent VLP's (Fig. 5).

With the highest energy levels of the VLPs being logged before the explosions, these events seem to have been one of the detonators of the explosions (Fig. 5b). They seemed to herald that magma/fluids were ascending. Of particular note was the VT/LP swarm of the 13th-14th of August that began $12 \mathrm{~h}$ before the hydromagmatic eruptions on the morning of 14 August (Fig. 11). The swarm comprised of some 40 VTs and $>50$ LPs was the most energetic of any seismic swarm registered at Cotopaxi since 2002 and was a warning in hindsight which presaged the subsequent explosions/strong emissions some hours later. These seismic trends and the higher $\mathrm{SO}_{2}$ flux, would indicate that magma was working in the upper part of the system - at least in the 0 to $6 \mathrm{~km}$ level below the crater.

The initial explosions had a phreatic component since water was available in the small pond at the crater's base, sub-glacial melting and from pore water within the hydrothermal system. Nonetheless, Gaunt et al. (2016) argued that the most likely driving force of the initial explosions was magmatic heat interacting with the hydrothermal system providing energy to trigger hydromagmatic eruptions at Cotopaxi. Textural evidence for this process was only preserved in the deposits of the initial eruptions, but not subsequent ones. Later emissions were likely the result of the repeated formation and destruction of a shallow magmatic plug by brittle fragmentation through mechanical stresses and decompression. Gas overpressure must have been accumulating beneath the conduit plug and may have contributed to the flank deformation, particularly as registered by the tiltmeters. In the succeeding post-explosion days $\mathrm{SO}_{2}$ output rose to 16,000-18,000 ton/day (Hidalgo et al. 2016), a likely testimony to the accumulated gas that had been trapped in the plumbing system.

The expulsed material showed evidence of strong hydrothermal alteration and there was initially little evidence of juvenile components. There was also a low $\mathrm{pH}$ (3.6-5.1) and high sulfate- $\mathrm{SO}_{4}$ concentrations (up to $13,000 \mathrm{mg} / \mathrm{kg}$ ) in the expulsed ashes of the 14th to 25th of August, as detected by leachate analysis (P. Delmelle, Pers. Comm, 2015). Later, as described above, the percentage of juvenile components increased through time, to the last erupted material collected in late November, 2015.

After the explosions and strong emissions of the 14th of August, the conduit lost its retaining plug and remained open and continual fluid movement was facilitated, although pulsatile superficial activity continued, and few shallow explosions occurred. After the explosions LP events were initially high (>200 events/day), but dropped to $<20$ events/day by the first week of September, where they remain at this writing.

While the LPs diminished, to the contrary the VT events rose notably. Around the 1st of September 15-20 LP events/day were registered. By the third week of September these increased to $>200$ events/day (Fig. 16), and subsequently this value decreased to 50-100 events/day, but in all totaled nearly 15,000 events. In the last 3 months of 2015 persistent VT daily activity was registered as well as waning tilt and GPS offsets. Even with the VT swarm overall seismic energy levels decreased compared to the levels registered in May to August, which may be due to the overall successful degassing of the system, but could also be explained by closing of the conduit by a degassed magma column, thus impeding freer liberation of gases. Between 

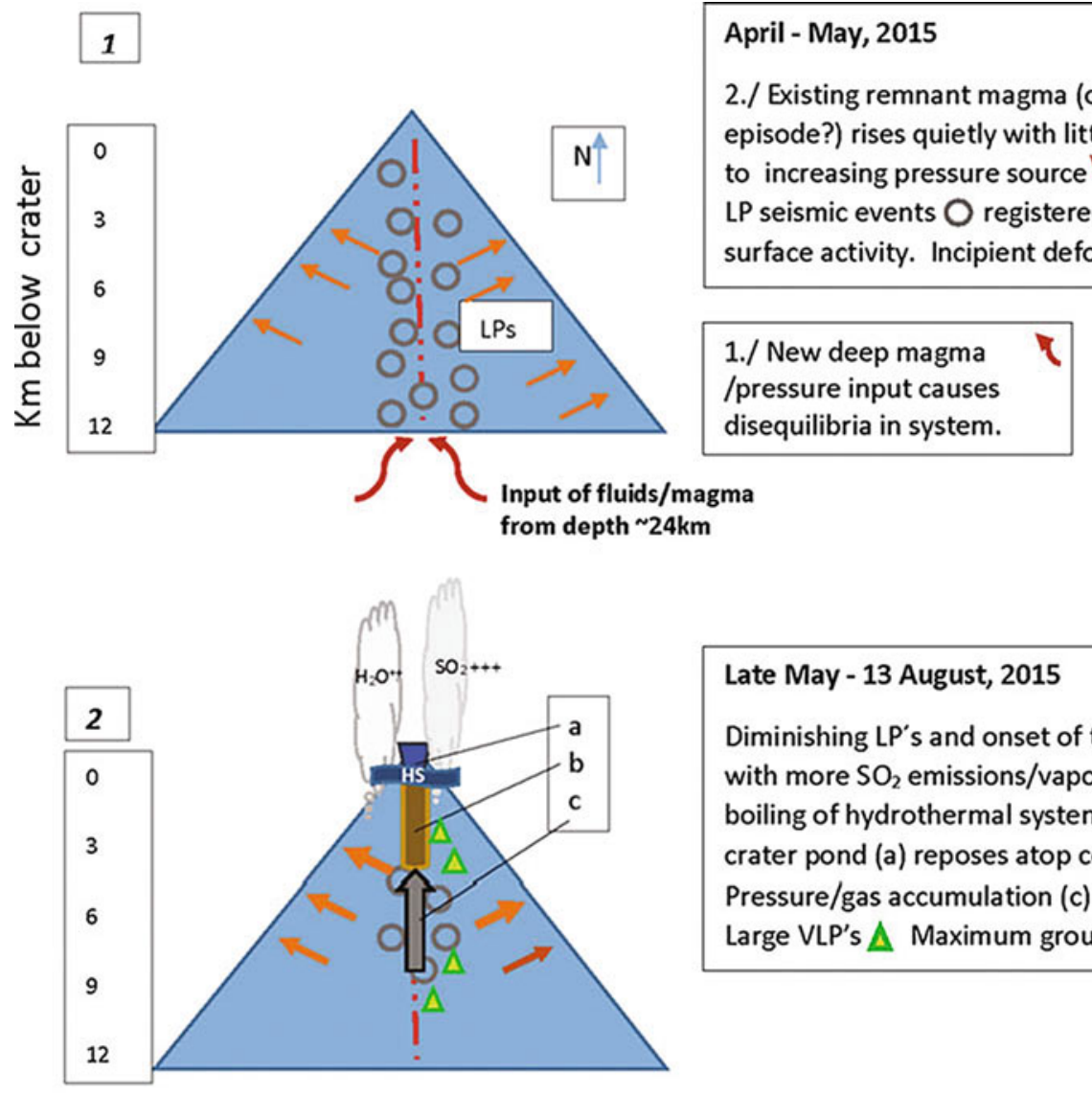

Late May - 13 August, 2015

Diminishing LP's and onset of tremor associated with more $\mathrm{SO}_{2}$ emissions/vapor columns and boiling of hydrothermal system (HS). Small crater pond (a) reposes atop conduit plug (b). Pressure/gas accumulation (c) beneath plug. Large VLP's $\Delta$ Maximum ground deformation.

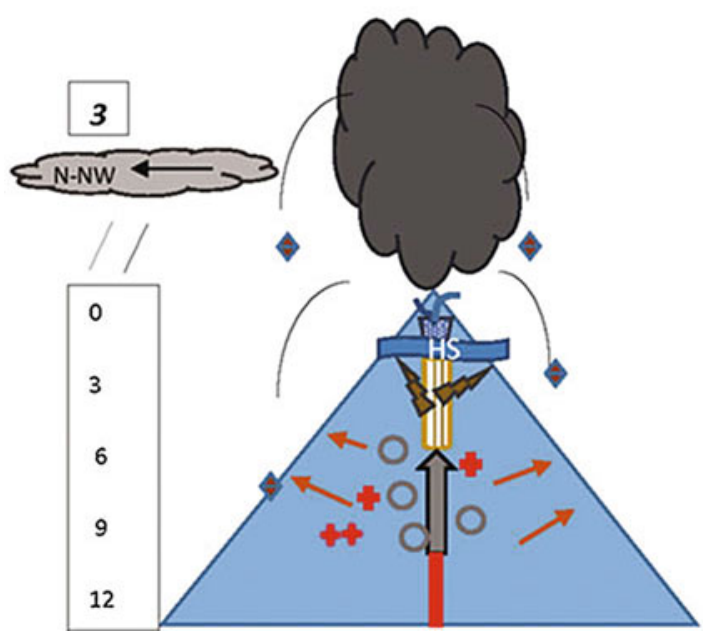

13-14 August, 2015- Explosions/Emissions

Swarm of LPs \& VTs \& anticipating main events. Fracturing of conduit plug and ensuing hydromagmatic explosions/emissions. Subsequent strong tremor related to gas and ash emissions. Continued deformation.

Fig. 18 Cartoons synthesizing the internal and superficial processes observed from April to December, 2015

October 2015 through April, 2016 internal explosions of deep providence were registered at a rate of 20-30 such events/month. These explosions could be interpreted as gas passing through restrictive areas within the conduit. While displaying only minimal infrasound and no detectable superficial vestiges, these explosions may be occurring due to pressurization 


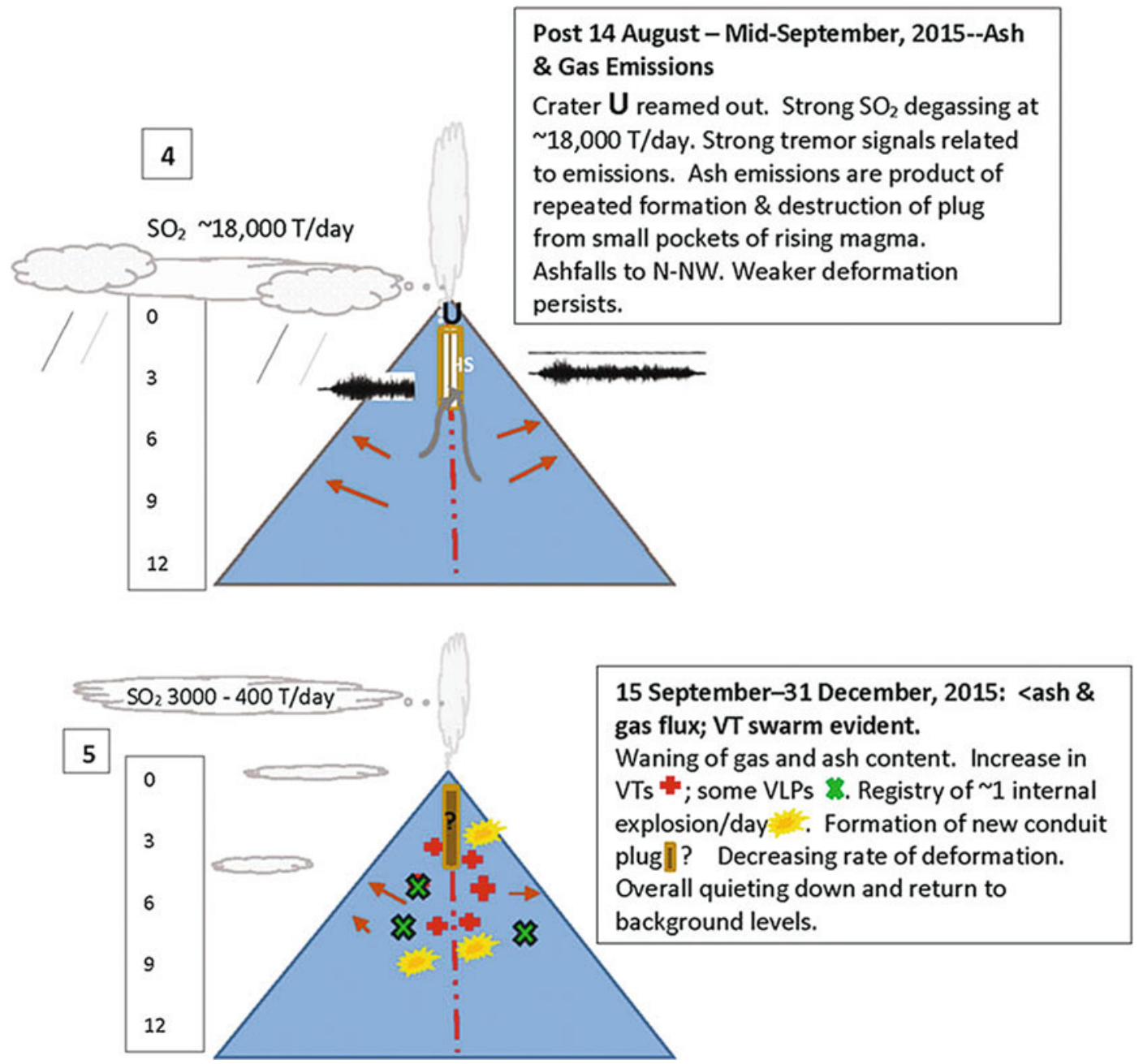

Fig. 18 (continued)

deep within the system (e.g. Valentine et al. 2014).

A synthesis of the 2015 unrest at Cotopaxi, the hypothesized driving forces and possible paths taken are shown in the following schematic cartoons (Fig. 18).

\section{The Science-Society Interface}

Strong evidence points to a magmatic component in Cotopaxi's 2015 reactivation and that this may be a precursor for future episodes, given that the bulk of the new magma that perturbed the system remained at depth. As a comparison, the 2001-2002 restless period had essentially been internal with only the weakest of superficial manifestations. For the 2015 reactivation IG scientists took the warnings very seriously and put all their collective experience to the test to make interpretations of the monitoring data and to manage successfully the great expectations of the public and authorities during the crisis period described above. Overall IGEPN volcanologists wrote 23 special reports that were disseminated via multiple media (www.igepn.edu.ec). Given the low levels of acceleration of seismic energy, small ground 
displacements and visual observations, eruption scenarios that the IGEPN formulated stayed within the realm of VEI 1-2 levels and clearly stated that the least likely scenarios was the generation of a paroxysmal eruption in which PDC's, voluminous ashfalls and giant lahars would be formed.

With each convincing sign that Cotopaxi was displaying stronger activity, IG scientists were proactive in improving and strengthening all monitoring systems while simultaneously helping to prepare the populations and authorities for what a major eruption of Cotopaxi could mean. Work by Christie et al. (2015) (an earlier VUELCO contribution) had shown that residents of the Chillos valley, to the east of Quito, were particularly ill-prepared to confront lahar hazards due to their recency of living in that valley. On the other hand, residents of the Latacunga valley had a clearer memory of lahar hazards, since many of their distant relatives had lived through Cotopaxi eruptions and their collective memory is better preserved. Nonetheless, social media, both beneficial and alarming, steered perceptions and actions of residents. The area of influence by the volcano, especially with respect with lahars, includes four important provinces, several counties and Quito's jurisdiction. It was particularly difficult to meet the demands and expectations and provide the personal attention of monitoring scientists to the authorities in each of these different municipalities as well as to meet with other community groups and respond to their uncertainties. There were also the constant attacks on social media of several particularly meanly-intentioned individuals who constantly tried to steer attention away from the IGEPNs scientific work by saying that it was operating with poor instrumentation or that the monitoring work at IGEPN was "carried out by amateurs".

All told, IGEPN scientists provided abundant custom guidance to local and national officials and residents with regards to volcano hazards and the proposed scenarios. A total of about 125 talks were given by IGEPN personal during the unrest period. Additionally, there was broad coordination with Ecuador's Secretary for Risk
Management at all levels and participation in guiding eruption simulations. Some of the discussions with them were based on what had been reviewed in the VUELCO workshop-simulated eruption exercises carried out in late 2014 in Quito. The IGEPN also greatly benefitted by the strong collaboration and presence of members of the USGS/USAID Volcano Disaster Assistance Team who led informed discussions on the trends of the geophysical precursors and also helped to reinforce the lahar-detection network. Personal from Chalmers University of Technology (Sweden), JICA (Japan), IRD (France) and NASA (USA), DEMEX-EPN with help in SEM, LMU-Germany with grain size X-ray diffraction and UCL (Belgium) with leachates, also collaborated during the crisis.

As the eruption process waned, it was obvious that high-risk populations were tired of being constantly alert and didn't want to be perpetually attentive to volcanic processes that could threaten their livelihoods and families. This issue will have to be acknowledged and dealt with in future reactivations.

\section{Conclusions}

Seismic activity and its evolution in event types, energy release, shallowing depths and locations, elevated degassing and ash emissions and flank deformation typified the restlessness of Cotopaxi during 2015. The important accumulative energy release first of LPs than followed by registry of an important suite of large VLP's was a significant geophysical pattern indicating fluid movement, followed then by a more convincing transfer up conduit of small slugs of magma and gases to beneath the conduit plug. In the late hours of the 13th of August this plug fractured and ruptured, evidenced by the vigorous swarm of VTs and LPs before the hydromagmatic explosions that occurred early on the 14th of August 2015. Minor ground deformation, the small, limited explosions in August and subsequent ash emission suggest that the ascended magma volume was small, and indeed as calculated by Bernard et al. (2016), was only about 
$0.5 \mathrm{Mm}^{3}$ DRE. This value is far inferior to the possible volume of $42 \pm 26 \mathrm{Mm}^{3}$, which is hypothesized to be at depth based on modeling of the observed GPS displacements (Mothes et al. 2016b). A second energetic magmatic pulse did not arise, and certainly not one with a sufficient volume to produce a VEI 3 or 4 eruption, which was one of the least likely scenarios, but nonetheless dreaded by the society and scientists.

Following the 14 August explosions and subsequent ash emissions we did not observe a new phase of outward GPS displacement trends in the deformation data, which could have implied a new magma input to cause another phase of deformation. The post-explosion VT seismic swarm which lasted 5 months was indicative of persistent internal perturbation but did not transpire in a new phase of deformation, thus we assumed that we were dealing with a small magma volume. The magma that tipped off the 2015 unrest may have been a remnant of that which provoked the 2001-2002 episode and was reported by Hickey et al. (2015). This residual magma could have been disturbed by the ascending heat and fluids from the new magma input at depth $(\sim 24 \mathrm{~km})$ whose source was possibly under the SE flank, and which provoked the recorded ground deformation and the LP and VLP seismicity.

The volcano was benevolent and had awakened to only a VEI 2 level. No major damage was imparted upon the population or on livelihoods, except for temporary local economic depression, increased anxiety of the population, mild crop losses and premature selling of livestock due to fears of future losses. Overall, the volcano's manifestations served as a warning to everyone to keep attentive of Cotopaxi's capacity to cause destruction and possible severe ruin by lahar transit down major drainages which are heavily populated and host important strategic infrastructure.

An eruption process can last months to decades, and we need only to look at Tungurahua, an andesitic stratocone also in Ecuador's Cordillera Real, with ongoing eruptions for 17 years (Mothes et al. 2015a, b), or Soufrière Hills on
Montserrat (Sparks and Young 2002) to suggest that the next round of Cotopaxi eruptions could last more than just several months. In the case of Tungurahua, activity started gradually in 1999 and displayed oscillating low-level behavior over the years to finally generate a rapid-onset VEI 3 eruption in 2006 (Hall et al. 2013). Such long waits test the population's resilience, but is also a time for monitoring scientists to become acquainted with the volcano's eruption style. During a reactivation period of a long dormant volcano there are many uncertainties and this demands stringent work and continual mindfulness by monitoring scientists and frequent ongoing interactive and personal communication with local communities and authorities.

During the 2015 unrest period at Cotopaxi, people living in high-risk zones (i.e. Latacunga and Valle de los Chillos) were swayed by speculation, rumors and lies concerning the status of the volcano. Some people also tended to weigh-in toward imprecise information posted on Facebook or Twitter and heed pseudo volcanologists and detractors, rather than rely on information from official channels. It was not uncommon to receive telephone calls from hysterical residents in either of these population centers inquiring if a Cotopaxi eruption was imminent? All told the IGEPN put out 3 reports each day about the volcano's activity and more than 24 special reports, all which are available on the IG website (www.igepn.edu.ec). The number of followers on the IGEPN's Facebook page grew to $>1$ million. To help stem the flow of bad information at the community level Ecuador's 911 system, in coordination with IGEPN personal, formed a pan-volcano vigía network comprised of volunteer observers who report via radio several times a day about their visual and audible observations of Cotopaxi or the rivers that are borne on it. This network with 55 volunteers, is in many ways a replica of the successful community-based vigia system that has functioned at Tungurahua volcano since 2001 (Stone et al. 2014; Mothes et al. 2015b). The information provided by the vigía volunteers compliments the ongoing geophysical monitoring and also serves to strengthen their capacities 
as community leaders and guides during volcano crisis (Espín Bedón et al. 2016).

A hypothesis for a future trend in activity weighs heavily towards hydromagmatic to Vulcanian explosions which may have a rapid onset, similar to the 14th of August episode, then evolve to sub-Plinian to Plinian eruptions of VEI 3-4 magnitude, if enough magma has accumulated at a relatively shallow depth (maybe 0-7 km below the crater) as shown in Fig. 7 for the upper level seismicity, and can make it to the surface before degassing. Vulcanian eruptions have been prominent in the volcano's historical activity (Gaunt et al. 2015). Unraveling the story will be difficult.

As the volcano is well-monitored $24 \mathrm{~h} /$ day/365, we anticipate that the IGEPN will provide early warnings to the public and officials before onset of important eruptive activity. This 2015 "dry run" allowed for diversification and hardening of Cotopaxi's monitoring network, frequent preparation and reappraisal of eruption scenarios and for the creation of a society-wide discussion of the possible consequences of a large Cotopaxi eruption. Some of these steps were facilitated by previous work in a VUELCO workshop. Essentially, attending to the 2015 activity was an opportunity to test the level of preparedness of the scientists and of the Ecuadorian society. All IGEPN scientists strived hard to be ready to "call it right", had the occasion arisen and a large eruption was in preparation. Since so little new magma erupted and there was no detectable subsequent shallow magmatic recharge, we consider the eruption as extremely small, and that the residual magma is in repose until a future time. Overall, the crisis was an important opportunity for learning about Cotopaxi's restlessness, with particular recognition of the increase in the VLP events and their energy levels just weeks before the mid-August explosions and the synchronous but progressive ground deformation signals, albeit small, that coincided with the increased seismicity. These two patterns more than any other geophysical signals, announced the ascent of Cotopaxi's magma, although finally only a small quantity breached the surface.
In all likelihood little or no evidence of the 2015 restless period will be preserved in the geological record. We know from written chronicles (1534-1877) that Cotopaxi often had weeks to months of ramping up before unleashing VEI 3 or 4 eruptions, i.e. there were probably several poorly preserved 2015-sized like events, and therefore unrest has been poorly documented. In this recent case, scientists had the benefit of observing and analyzing the geophysical monitoring output during the entire episode and knowing what level of activity the volcano was at. But, monitoring scientists, just like the citizens of Ecuador, experienced the anxiety of pondering what could be the volcano's next steps, i.e., the possible rapid intrusion of a new batch of volatile-rich magma or returning to calm. Fortunately, in this time around, the first scenario did not transpire. However, this training opportunity that we experienced could prove invaluable for when the next scenario is played out.

Acknowledgements This work was supported by a grant from European Commission FP 7 program (ENV.2011.1.3.3-1; grant no: 282759; VUELCO). We would like to thank the IGEPN staff for keeping all monitoring operations at Cotopaxi volcano optimally functioning. Members of the IGEPN's Volcanology group gave most of the talks and explanations of eruptions scenarios to authorities, community groups and wherever was necessary during the crisis. We acknowledge the VUELCO project for opportunities to share opinions about future eruptive crisis scenarios. Also, we are grateful for the support of the VDAP/USAID team during the crisis. The EPN, SENESCYT and SENPLADES provided funding for much of the instrumentation and daily operations. Support by JICA instrumentation and guidance is also noted. The Ecuadorian military provided overflights of Cotopaxi, while IGM provided ortophotos. The LMI project was instrumental in carrying out near real time petrologic monitoring. Thanks to Viviana Valverde for preparation of several figures. Recognition is given to the expressions of interest by STREVA project members on the societal implications of eruptive activity at Cotopaxi.

\section{References}

Arias G (2015) Estudio de las Señales Sísmicas de Muy Largo Periodo del volcán Cotopaxi. Proyecto de Titulación, Facultad de Ciencias, Escuela Politécnica Nacional 
Arias G, Molina I, Ruiz M, Hernandez S, Alvarado A, Plain M, Mothes P, M Yépez, Hidalgo S, Barrington, C (2015) very long period seismicity accompanying increasing shallower activity at Cotopaxi Volcano. In Conference Paper No. S51D-2724, AGU Fall Meeting, San Francisco, 14-18 December

Bernard B, Battaglia J, Proaño A, Hidalgo S, Vásconez F, Hernandez S, Ruiz M (2016) Relationship between volcanic ash fallouts and seismic tremor: quantitative assessment of the 2015 eruptive period at Cotopaxi volcano, Ecuador. Bull Volcanol. doi:10.1007/ s00445-016-1077-5

Cáceres B (2016) Dramatic reduction of Cotopaxi glaciers during the last volcano awakening 2015-2016. Conference: AGU Fall Meeting, San Francisco-Moscone Center. doi:10.13140/RG.2.2.17483.80168

Chouet BA, Matoza RS (2013) A multi-decadal view of seismic methods for detecting precursors of magma movement and eruption. J Volcanol Geoth Res 252:108-175

Christie R, Cooke O, Gottsmann J (2015) Fearing the knock on the door: critical security studies insights into limited cooperation with disaster management regimes. J Appl Volcanol 4:19. doi:10.1186/s13617015-0037-7

Espín Bedón P, Mothes P, Montesdeoca M, Ruiz M, Alvarado A, Córdova M, Santamaria S (2016) Communication network of "Vigias" implemented at Cotopaxi Volcano, Ecuador, Abstract, Cities on Volcanoes-9, Puerto Varas, Chile, November, 2016

Garrison JM, Davidson JP, Hall M, Mothes P (2011) Geochemistry and petrology of the most recent deposits from Cotopaxi Volcano, Northern Volcanic Zone, Ecuador. J Petrol. doi:10.1093/petrology/ egr023

Gaunt HE, Mothes P, Chadderton A, Lavallee Y (2015) Physical characteristics of conduit plug rocks during Vulcanian eruptions at Cotopaxi and Tungurahua volcanoes, Ecuador. Abstract, IUGG meeting, Prague-Czech Republic, June 2015.

Gaunt EH, Bernard B, Hidalgo S, Proaño A, Wright H, Mothes P, Criollo E, Kueppers U (2016) Juvenile magma recognition and eruptive dynamics inferred from the analysis of ash time series: the 2015 reawakening of Cotopaxi volcano 328 October 2016. doi:10.1016/j.jvolgeores.2016.10.013

Hall M, Mothes P (2008) The rhyolitic-andesitic eruptive history of Cotopaxi volcano Ecuador. Bull Volcanol 70(6):675-702

Hall ML, Steele A., Mothes P, Ruiz M (2013) Pyroclastic density currents (PDC) of the 16-17 August 2006 eruptions of Tungurahua volcano, Ecuador: geophysical registry and characteristics. J Volcanol Geotherm Res 265(2013):78-93. https://doi.org/10.1016/j. jvolgeores.2013.08.011

Harlow DH, Power JA, Laguerta EP, Ambubuyog G, White RA, Hoblitt RP (1996) Precursory seismicity and forecasting of the June 15, 1991, eruption of Mount Pinatubo. Fire and Mud: Eruptions and Lahars of Mount Pinatubo, Philippines. University of Washington Press, Seattle, pp 285-306

Hemmings B, Whitaker F, Gottsmann J, Hawes MC (2016) Non-eruptive ice-melt driven by internal heat at glaciated stratovolcanoes. Submitted to $\mathrm{J}$ Vol Geotherm Res

Herring TA, King RW, Floyd MA, McClusky SC (2015) Introduction to GAMIT/GLOBK, Release 10.6. Department of Earth, Atmospheric, and Planetary Sciences, Massachusetts Institute of Technology, PSF: http://www-gpsg.mit.edu/ simon/gtgk/Intro_GG.pdf, $50 \mathrm{p}$

Hickey J, Gottsmann J, Mothes P (2015) Estimating volcanic deformation source parameters with a finite element inversion: The 2001-2002 unrest at Cotopaxi volcano, Ecuador. Journal of Geophysical Research: Solid Earth 120(3):1473-1486

Hidalgo S, Bernard B, Battaglia B, Gaunt E, et al. (2016) Cotopaxi volcano's unrest and eruptive activity in 2015: mild awakening after 73 years of quiescence. Geophys Res Abstracts Vol. 18, EGU2016-5043-1, 2016 EGU General Assembly, Viena-Austria

Jousset P, Budi-Santoso A, Jolly AD, Boichu M, Dwiyono S, Sumarti S, Hidayati S, Thierry P (2013) Signs of magma ascent in LP and VLP seismic events and link to degassing: an example from the 2010 explosive eruption at Merapi volcano, Indonesia. J Volcanol Geoth Res 261:171-192. doi:10.1016/j.jvolgeores. 2013.03.014

Kumagai H, Yepes H, Vaca M, Caceres V, Nagai T, Yokoe K, Vasconez F (2007) Enhancing volcano-monitoring capabilities in Ecuador. Eos 88 (23):245-252

Kumagai H, Palacios P, Maeda T, Castillo DB, Nakano M (2009) Seismic tracking of lahars using tremor signals. J Volcanol Geoth Res 183(1):112-121

Kumagai H, Nakano M, Maeda T, Yepes H, Palacios P, Ruiz M, Yamashima T (2010) Broadband seismic monitoring of active volcanoes using deterministic and stochastic approaches. J Geophys Res: Solid Earth 115 (B8)

Kumagai H, Mothes P, Ruiz M, Maeda Y (2015) An approach to source characterization of tremor signals associated with eruptions and lahars. Earth, Planets, and Space. 67:178, 67:178, doi:10.1186/s40623-0150349-1

Lyons J, Segovia M, Ruiz M (2012) Reporte del Enjambre Sísmico en la Zona de Volcán de Cotopaxi-Mayo 2012. Internal report. Not published. IGEPN, Quito.

Maeda Y, Kumagai H, Lacson RJ, Figueroa MS, Yamashina T, Ohkura T, Baloloy AV (2015) A phreatic explosion model inferred from a very long period seismic event at Mayon Volcano, Philippines. J Geophys Res Solid Earth 120:226-242. doi:10.1002/ 2014JB011440

Márquez M (2012) Caracterización de los sismos de muy largo periodo en el volcán Cotopaxi y sus implicaciones. Tesis de Grado, Carrera de Geofísica, Facultad 
de Ciencias Astronómicas y Geofísicas, Universidad Nacional de La Plata. Argentina

Marzocchi W, Newhall CG, Woo G (2012) The scientific management of volcanic crises. J Volcanol Geoth Res 247-248:181-189

Molina I, Kumagai H, García-Aristizábal A, Nakano M, Mothes P (2008) Source process of very-long-period events accompanying long-period signals at Cotopaxi Volcano, Ecuador. J Volcanol Geoth Res 176(1):119_ 133

Moran SC, Newhall C, Roman DC (2011) Failed magmatic eruptions: Late-stage cessation of magma ascent. Bull Volc 73(2):115-122. doi:10.1007/ s00445-010-0444-X

Mothes P, Hall ML, Espín, PA, Vasconez F, Sierra D, Córdova M, Santamaría S, Andrade D (2016a) Mapa Regional de las Amenazas del Volcán Cotopaxi- Norte and Sur, scale 1:50,000, Instituto Geofísico and Instituto Geografico Militar, Quito http://www.igepn. edu.ec/mapas/mapas-volcan-cotopaxi.html

Mothes PA, Nocquet JM, Jarrín Tamayo P, Morales Rivera AM, Lundgren PR, Yépez YM, Viracucha EG, Gaunt EH (2016b) Geodetic signature associated with unrest at Cotopaxi in 2015-2016: modeling of GPS data, a deep magma source, synchronous seismic swarms and petrologic constraints. Abstract, Cities on Volcanoes-9, Puerto Varas, Chile, November, 2016

Mothes P, Hall ML, Andrade D, Yepes H, Pierson TC, Ruiz AG, Samaniego P (2004) Character, stratigraphy and magnitude of historical lahars of Cotopaxi volcano (Ecuador). Acta Vulcanol 16(1/2):1000-1023

Mothes P, Lisowski M, Ruiz M, Ruiz G, Palacios P (2010) Borehole Tiltmeter and CGPS Response to VLP Seismic Events under Cotopaxi Volcano. Ecuador, Fall AGU, San Francisco Abstract

Mothes PA, Vallance JW, Hall ML, Garrison JM (2015a) Cotopaxi's most recent rhyolitic eruptions, $2800 \mathrm{y}$ BP. In Conference Abstract, 26th IUGG General Assembly, Prague

Mothes PA, Yepes HA, Hall ML, Ramón PA, Steele AL, Ruiz MC (2015b) The scientific-community interface over the fifteen-year eruptive episode of Tungurahua Volcano Ecuador. J Appl Volcanol 4(1):1-15

Mothes PA, Vallance JW (2015) Lahars at Cotopaxi and Tungurahua Volcanoes, Ecuador: highlights from stratigraphy and observational records and related downstream hazards. In Volcanic Hazards, Risks and Disasters. doi:10.1016/B978-0-12-396453-3.00006-X, chapter 6

Newhall CG (2000) Volcano Warnings. In: Sigurdsson et al. (Eds) Encyclopedia of Volcanoes. San Diego, CA, pp 1185-1198

Newhall, Christopher G, Self Stephen (1982) The Volcanic Explosivity Index (VEI): An Estimate of Explosive Magnitude for Historical Volcanism (PDF). J Geophys Res. 87 (C2): 1231-1238.
Bibcode:1982JGR...87.1231 N.

doi:10.1029/ JC087iC02p01231

Nocquet JM, Villegas-Lanza JC, Chlieh M, Mothes PA, Rolandone F, Jarrin P, Martin X (2014) Motion of continental slivers and creeping subduction in the northern Andes. Nat Geosci 7(4):287-291

Phillipson G, Sobredelo R, Gottsmann J (2013) Global volcanic unrest in the 21 st century: an analysis of the first decade. J Volcanol Geother Res 264:183-196. doi:10.1016/j.jvolgeores.2013.08.004

Pistolesi M, Rosi M, Cioni R, Cashman KV, Rossotti A, Aguilera E (2012) Physical volcanology of the posttwelfth-century activity at Cotopaxi volcano, Ecuador: behavior of an andesitic central volcano. Geol Soc Am Bull 123(5-6):1193-1215

Power JA, Stihler SD, Chouet BA, Haney MM, Ketner DM (2012) Seismic observations of Redoubt Volcano, Alaska-1989-2010 and a conceptual model of the Redoubt magmatic system. J Volcanol Geotherm Res 259:31-44

Ruiz M, Guillier B, Chatelain JL, Yepes H, Hall M, Ramon P (1998) Possible causes for the seismic activity observed in Cotopaxi volcano Ecuador. Geophys Res Lett 25(13):2305-2308

Siebert L, Simkin T, Kimberly P (2010) Volcanoes of the World. Univ. of California Press and Smithsonian Institute. $551 \mathrm{p}$

Sparks RSJ, Aspinall WP (2004) Volcanic activity: frontiers and challenges in forecasting, prediction and risk assessment. The State of the Planet: Frontiers and Challenges in Geophysics, Geophysical Monograph 150, IUGG Volume 19

Sparks RSJ, Young SR (2002) The eruption of Soufrière Hills Volcano, Montserrat (1995-1999): overview of scientific results Geological Society, London, Memoirs 21:45-69. doi:10.1144/GSL.MEM.2002.021.01. 03

Stone J, Barclay J, Simmons P, Cole PD, Loughlin SC, Ramón P, Mothes P (2014) Risk reduction through community-based monitoring: the vigias of Tungurahua Ecuador. J Appl Volcanol Soc Volcanoes 3:11. doi:10.1186/s13617-014-0011-9

Tilling RI (1989) Volcanic hazards and their mitigation: progress and problems. U.S. Geological Survey, Menlo Park, California, p p33

Valentine G, Graettinger AH, Sonder I (2014) Explosion depths for phreatomagmatic eruptions. Geoph Res Lett doi:10.1002/2014GL060096

White R, McCausland W (2016) Volcano-tectonic earthquakes: A new tool for estimating intrusive volumes and forecasting eruptions. J Volcanol Geoth Res 309:139-155

Zobin, VM (2012) Long-Period and Very Long-Period Seismic Signals at Volcanoes. In: Zobin (Ed), VM Introduction to Volcanic Seismology (2nd ed). pp 327-354 
Open Access This chapter is licensed under the terms of the Creative Commons Attribution 4.0 International License (http://creativecommons.org/licenses/by/4.0/), which permits use, sharing, adaptation, distribution and reproduction in any medium or format, as long as you give appropriate credit to the original author(s) and the source, provide a link to the Creative Commons license and indicate if changes were made.
The images or other third party material in this chapter are included in the chapter's Creative Commons license, unless indicated otherwise in a credit line to the material. If material is not included in the chapter's Creative Commons license and your intended use is not permitted by statutory regulation or exceeds the permitted use, you will need to obtain permission directly from the copyright holder. 